
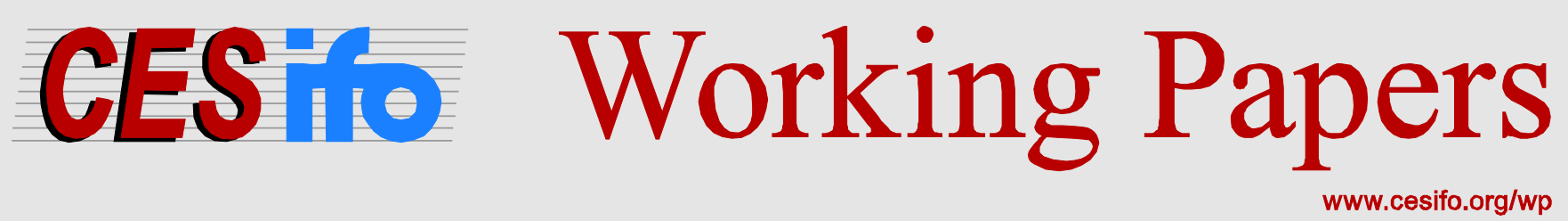

\title{
Unobserved Tax Avoidance and the Tax Elasticity of FDI
}

\author{
Peter Egger \\ Valeria Merlo \\ Georg Wamser
}

CESIFO WORKING PAPER NO. 4921

CATEgory 1: Public FinANCE

JULY 2014

An electronic version of the paper may be downloaded

- from the SSRN website:

- from the RePEc website:

- from the CESifo website:

WWW.SSRN.com

www.RePEc.org

www.CESifo-group.org/wp

\section{CESifo}




\title{
Unobserved Tax Avoidance and the Tax Elasticity of FDI
}

\begin{abstract}
This paper investigates the tax responsiveness of multinational firms' investment decisions in foreign countries, distinguishing firms that are able to avoid taxes (avoiders) from those that are not (non-avoiders). From a theoretical point of view, the tax responsiveness of firms crucially depends on this distinction. Empirically, however, a firm's ability to avoid profit taxes is inherently unobservable to the researcher. To address this problem, we use a finite mixture modeling approach which allows us to distinguish avoiders from non-avoiders stochastically from a mixture of distributions of the two types of firms. Using panel data on the universe of foreign affiliates of German multinational firms over the years 1999 to 2010, we find that investments of tax avoiders do not respond to host-country profit taxes at all, while those of non-avoiders do. About $11 \%$ of the affiliates are estimated to be able to avoid taxes. These investments account for about $58 \%$ of the stock of foreign fixed assets held by German multinational firms abroad. A one-percentage-point increase in the statutory corporate profit tax rate of a host country is found to reduce the fixed assets of non-avoiders in that host country by $0.81 \%$.
\end{abstract}

JEL-Code: C350, C380, F230, H320.

Keywords: corporate profit taxation, multinational firms, profit shifting, tax avoidance, tax elasticity, finite-mixture model, firm-level data.

\author{
Peter Egger \\ ETH Zurich / KOF \\ Weinbergstrasse 35, WEH E6 \\ Switzerland-8092 Zurich \\ egger@kof.ethz.ch \\ Valeria Merlo \\ University of Tübingen \\ Mohlstr. 36 \\ Germany - 72070 Tübingen \\ valeria.merlo@uni-tuebingen.de \\ Georg Wamser \\ University of Tübingen \\ Mohlstr. 36 \\ Germany-72070 Tübingen \\ georg.wamser@uni-tuebingen.de
}




\section{Introduction}

A vast amount of empirical research on the profit-tax responsiveness of foreign direct investment (FDI) suggests a robust negative impact of profit taxation on the location and size of foreign investments by multinational enterprises (MNEs). In a meta-analysis on the matter, De Mooij and Ederveen (2003) find that the median semi-elasticity amounts to -3.3 . Hence, a one-percentage-point increase in a host country's (corporate) profit tax rate triggers, ceteris paribus, a decline of FDI by about $3.3 \%$ there ${ }^{1}$ However, the same study by De Mooij and Ederveen (2003) also documents a big variance of the estimated profit tax elasticities of FDI across studies. Common explanations for the latter are the differences in the applied empirical specifications and the data used. Yet, differences in tax elasticities may also be rationalized by the specific responses of heterogeneous firms.

Differences in the characteristics of MNEs - such as their geographical affiliate pattern, their financial flexibility, their specialization pattern, firm size, etc. - explain why some firms enter a specific market and others do not. Moreover, such characteristics crucially determine whether and to what extent an MNE can reduce its overall tax burden and, hence, its responsiveness to profit taxes. While all firms may try to avoid taxes through using financial instruments associated with preferential tax treatment or through tax exemptions related to specific activities such as investment in R\&D, examining MNEs may be particularly interesting in this context since they can avoid taxes through shifting profits from high- to low-tax countries to reduce their tax burden. In this regard, previous empirical work on MNEs' profit shifting activities provides implicit evidence on shifting and avoiding (and its volume) for the average $\left.\mathrm{MNE}\right|^{2}{ }^{3}$

\footnotetext{
${ }^{1} \mathrm{~A}$ more recent study of De Mooij and Ederveen (2006) finds a somewhat smaller median semi-elasticity of -2.1 . Hines (1999) suggests an average profit tax elasticity of FDI of about -0.60 .

${ }^{2}$ For instance, Egger, Eggert, and Winner (2010) report that tax payments of foreignowned firms are lower than those of domestic firms in high-tax countries, but higher in low-tax countries, which is consistent with the presumption that MNEs shift income, on average.

${ }^{3}$ Note that we use the term "tax avoidance" rather broadly for all situations where a firm can "avoid" (not necessarily in an illegal manner) tax payments for a marginal investment project. Of course, this might be the case for a number of reasons and generally depends on tax law on the one hand, and on firm characteristics on the other. It includes considerations about tax incidence but also about income shifting of multinational firms. In the former case, a higher corporate tax may be avoided by shifting the tax burden to
} 
However, neither are all MNEs likely able to fully avoid taxes nor are all affiliates in an MNE likely involved in these activities. This raises questions of the following kind. How big is the fraction of profit-tax avoiders among a country's MNEs and their affiliates? What are the tax (semi-)elasticities of foreign investments by avoiders versus non-avoiders? Such questions have apparently not been posed for two reasons. Which firms, MNEs in particular, and affiliates engage in tax avoidance (e.g., through profit shifting), and which ones do not is not directly observable in data, and the econometric models commonly employed do not permit distinguishing avoiders from nonavoiders on stochastic grounds.

Knowing about the number and characteristics of tax avoiding versus nonavoiding units is interesting not only to the economist but also to the policy maker. With a coexistence of avoiding and non-avoiding MNEs, knowledge of an average rate of profit tax response of aggregate FDI is not informative. It conceals information about the heterogeneity of tax responses between avoiders and non-avoiders and - in case of a complete unresponsiveness of avoiders to profit taxes - about the number of firms and their characteristics in a jurisdiction that are affected by tax policy at all. The latter is vital for determining the relevant tax base and for predicting the response of tax revenues to policy changes.

This paper sheds light on the impact of corporate profit taxes on direct investments in foreign affiliates of the universe of German MNEs by allowing for distinct responses of inherently unobserved avoiders and non-avoiders of profit taxes. Foreign investments in affiliates which are capable of avoiding taxation at least partly, e.g., by profit shifting, should be less affected by (i.e., less responsive to) profit taxes than others. Hence, non-avoiders should face higher costs of capital and, in turn, lower levels of investment in high-tax host countries than avoiders 4

other factors of production. In the latter case, tax payment may be avoided through tax base shifting to low-tax entities. While income shifting is relevant only in the context of multinational firms (this paper uses data on MNEs), we define "tax avoidance" as all activities that allow a firm to reduce taxes at the intensive investment margin (this includes the use of debt financing, depreciation allowances, preferential tax credits provided by local governments, etc.). If taxes can be avoided, we expect that investment decisions are not distorted by the tax on corporate profits and the tax response is zero.

${ }^{4}$ This line of reasoning is consistent with theoretical work emphasizing that restrictions on the opportunities for tax planning may result in adverse consequences for MNEs' investment in high-tax countries, which subsequently may reinforce tax competition (see, for example, Keen, 2001; Janeba and Smart, 2003; Peralta, Wauthy, van Ypersele, 2006; Bucovetsky and Haufler, 2008; Haufler and Runkel, 2010). 
The main goal of this paper is to provide evidence on the relative number of profit shifting units and their characteristics among the universe of a large country's MNEs and their foreign affiliates in spite of their profit shifting being inherently unobservable. This is accomplished by using a finite mixture stochastic model (see Heckman and Singer, 1984) as a novel approach to estimate the different tax responsiveness of latent profit tax avoiders and non-avoiders. The latter entails a semiparametric approach to modeling the unobserved heterogeneity between tax avoiders and non-avoiders. The universe of MNEs and their foreign affiliates in the data are assumed to be composed of a finite number (here, two: one for the avoiders and one for non-avoiders) of distinct but unidentified latent classes or population components..$^{5}$ More specifically, the density of all investments in foreign affiliates is modeled as an additive mixture of the two subpopulations. Any randomly drawn observation has a given a priori probability of belonging to one of the groups - avoiders and non-avoiders of profits. This probability is estimated along with other model parameters, and it is assumed either constant and equal to the proportion of firms in that group $4^{6}$ or it is parameterized and modeled as a function of observables which vary across units.

We identify two groups of firms which differ in their average investment levels and their responsiveness to corporate profit taxation. The larger group of about $89 \%$ of the foreign affiliates which are held by about $76 \%$ of the MNEs in the data is not able to avoid profit taxes and reacts negatively to corporate tax rates. The estimated tax semi-elasticity of these firms is about -0.81 (which is significantly smaller than average semi-elasticities based on aggregate FDI). The smaller group of about $11 \%$ of foreign affiliates which are held by $24 \%$ of Germany's MNEs is estimated to be capable of tax avoidance. These avoiders do not display any significant response to profit taxation in a host country, and they display an average investment level which exceeds the one of non-avoiders by more than $1000 \%$. Altogether, $58 \%$ of the stock of foreign fixed assets but only a relatively small share of foreign affiliates held by German MNEs is estimated to be insensitive (and unexposed) to foreign corporate profit taxation.

\footnotetext{
${ }^{5}$ In principle, we can allow for more than just two classes of firms that vary in their tax responsiveness. However, tests point to the existence of two groups rather than three or four. In every case we identify one group of firms which does not react to taxes at all. While the group of firms that do react to taxation can further be divided into additional subgroups, the estimated tax elasticities across subgroups are very similar.

${ }^{6}$ The results assuming a constant-only model are suppressed here and only briefly discussed but are available upon request from the authors.
} 
As mentioned above, in our preferred specification, a one-percentagepoint increase in the statutory profit tax rate is associated with a reduction of the stock of fixed assets of a non-avoiding foreign affiliate by $0.81 \%$. Since the stock of fixed assets of the average non-avoiding foreign affiliate amounts to 10.98 million Euros, the estimated response corresponds to approximately 88,922 Euros. The stock of fixed assets of the average profit-tax-avoiding foreign affiliate amounts to about 119.67 million Euros. If tax avoidance of such affiliates were prevented and they were to respond to corporate tax rates in the same way as the non-avoiding affiliates, the estimated semi-elasticity would imply an aggregate reduction of almost 1 million Euros of fixed assets of German MNEs per percentage-point of a profit-tax increase.

While previous research estimates an average tax response over all (heterogeneous) firms, the finite mixture approach does not only emphasize that one group of firms (avoiders) is not responding to taxes at all, it also permits estimating an average tax effect for a second group of firms (non-avoiders) that responds to profit taxes. In particular, the approach provides estimates of how many and which firms belong in either one of the two groups, which is not directly observable. Our findings appear informative for the general assessment of tax incidence - since it seems that one group of firms can fully avoid taxation - and they carry important implications for tax policy.

The remainder of the paper is organized as follows. Section 2 discusses the empirical literature on corporate profit taxation and MNEs. Section 3 presents a very simple model, briefly demonstrating how the tax elasticity of capital depends on the extent to which a firm is able to avoid taxes. Section 4 describes the econometric model applied and the panel data-set used for the empirical investigation. The results are discussed in Section 5, and Section 6 concludes.

\section{State of Empirical Research on Corporate Profit Taxes and MNEs}

Our study closely relates to the empirical literature on the consequences of profit taxation on MNE behavior, which is basically organized along four lines of interest.

A first strand of work focuses on the role of corporate profit taxes for the location decision of firms' lumpy investments (for example, Devereux and Griffith, 1998, 2003; Buettner and Ruf, 2007; Barrios, Huizinga, Laeven, 
Nicodème, 2008; Becker, Egger and Merlo, 2012).

A second line of research is concerned with the question of how corporate profit taxes affect a firm's level of FDI or assets held abroad (for a review and meta-studies of empirical work see De Mooij and Ederveen, 2003, 2006, 2008).

A third category of work is interested in the extent of tax avoidance through profit shifting (Grubert and Mutti, 1991; Hines and Rice, 1994; Huizinga and Laeven, 2008; Weichenrieder, 2009; Egger, Eggert, Winner, 2010), debt shifting (Huizinga, Laeven, and Nicodème, 2008; Buettner and Wamser, 2012; Egger, Eggert, Keuschnigg, Winner, 2010; Egger, Keuschnigg, Merlo, and Wamser, 2014), or transfer pricing (Swenson, 2001; Clausing, 2003).

A fourth subliterature investigates how investment decisions of firms are affected by tax-planning strategies. In particular, proponents of such research found that the tax responsiveness of investments depends on characteristics

of the host country tax system such as the method of double taxation relief applied (Hines, 1996) or the level of the corporate profit tax rate (Overesch, 2009), as well as on firm characteristics which co-determine profit-shifting opportunities (Overesch and Wamser, 2009).

All of the aforementioned work suggests that tax bases may be, at least to some extent, unbundled from real economic activity. Hence, profit taxes have a limited relevance for location and investment decisions of (some) MNEs. In particular, the ability to avoid profit taxes should reduce the profit tax responsiveness of firms' activities such as their real investments. Yet, little to nothing is known to this date about the scope of tax avoidance in general and about profit shifting in particular in terms of numbers of firms and affiliates engaging in it and the relative responsiveness of avoiders versus non-avoiders to profit taxation. The present paper aims at bridging this gap by providing first estimates related to these issues.

\section{Tax Avoidance and the Tax Responsiveness of Capital}

To see how firms' investments may differ with respect to their tax elasticities, consider a very simple model of investment of a firm. Suppose the firm is an MNE and maximizes profits $\Pi$ of a foreign subsidiary $i$. To keep the analysis simple, let us assume that capital $K_{i}$ is the only factor of production. Denote 
the cost of capital by $r_{i}$. Output is produced through the technology $F\left(K_{i}\right)$, which has standard properties such as $F^{\prime}\left(K_{i}\right)>0$ and $F^{\prime \prime}\left(K_{i}\right)<0$. Let $\tau_{i}$ denote the local tax rate that applies to $i$ and let $\phi_{i} \in[0,1]$ denote the degree of tax avoidance (e.g., through profit shifting, transfer pricing, debt financing, royalty payments, or all other measures and strategies that allow for a reduction of tax base). Then, after normalizing the price of output to unity without loss of generality, profits (which are also the tax base) are defined as

$$
\Pi_{i}=F\left(K_{i}\right)-\tau_{i} F\left(K_{i}\right)\left(1-\phi_{i}\right)-r_{i} K_{i} .
$$

In general, the total tax payments by unit $i$ amount to $\tau_{i}\left(F\left(K_{i}\right)\left(1-\phi_{i}\right)\right)$. Without any tax avoidance $\left(\phi_{i}=0\right)$, the tax payments are $\tau_{i} F\left(K_{i}\right)$; and if the firm is able to completely avoid taxes through, say, profit shifting $\left(\phi_{i}=1\right)$, they are zero. The profit-maximizing capital stock can be found from differentiating (1) with respect to $K_{i}$ which yields

$$
F^{\prime}(K)=\frac{r_{i}}{1-\tau_{i}\left(1-\phi_{i}\right)}
$$

With the assumed properties of $F\left(K_{i}\right)$, this directly implies that non-avoiders with $\phi_{i}=0$ require a higher marginal return to capital than avoiders. In contrast, with full profit tax avoidance $\phi_{i}=1$, the profit-maximizing capital stock is independent of $\tau_{i}$. In view of (2), the tax responsiveness of $K_{i}$ can be written as

$$
\frac{d K_{i}}{d \tau_{i}}=\frac{\left(1-\phi_{i}\right) F^{\prime}\left(K_{i}\right)}{F^{\prime \prime}\left(K_{i}\right)\left[1-\tau_{i}\left(1-\phi_{i}\right)\right]}<0 .
$$

Equation (3) implies that the tax responsiveness of $K_{i}$ approaches zero as $\phi_{i}$ approaches unity. For all values of $\phi_{i} \in(0,1]$, the tax response of a firm is smaller (less negative) compared with the case of no tax avoidance at $\phi_{i}=0$. In the subsequent analysis we do not focus on specific channels explaining firm heterogeneity in $\phi$ and generally allow for all possible (legal and illegal) mechanisms companies might use to reduce their tax bases and avoid taxes.

\section{Empirical Approach}

\subsection{A Two-component Finite Mixture Model}

We are interested in the tax elasticity of the fixed assets of foreign affiliates

of German MNEs. We expect tax responses of foreign affiliates that are able 
to avoid taxes (avoiders) to differ from those of affiliates which are not able to avoid taxes (non-avoiders). As outlined in Section 3 , non-avoiders are expected to be affected by corporate profit taxation, and thus have higher costs of capital and lower levels of fixed assets than avoiders at positive tax rates.

However, whether an affiliate avoids profit taxes or not is unobserved. One way to approach this problem empirically is in terms of a latent class analysis: the population of affiliates is then considered to be composed of two underlying latent classes or population components (see Aitkin and Rubin, 1985). We use a finite mixture model to estimate the different tax responsiveness of tax avoiders $(a)$ and non-avoiders $(n)$. The whole sample of affiliates is modeled as a probabilistic mixture from the two subpopulations with different densities (while these differ in their moments, they follow the same distributional form).

Let $y_{i t}$ denote the stock of fixed assets of affiliate $i=1, \ldots, N$ in period $t=1, \ldots, T]^{7}$ Outcome $y_{i t}$ is characterized by one of two different densities $f^{\ell}, \ell=\{a, n\}$, with the same distributional form but different parameters $\boldsymbol{\theta}^{\ell}$, depending on whether affiliate $i$ is able to avoid profit taxes in period $t$ or not. Let $\mathbf{x}_{i t}$ be a $K \times 1$ vector of affiliate- and country-specific explanatory variables, and $c_{i}$ a time-invariant affiliate-specific effect.

Use $\pi^{n} \in[0,1]$ and $\pi^{a}=\left(1-\pi^{n}\right)$ to denote the fractions of affiliates that cannot and can, respectively, avoid profit taxes in period $t$, and let $f^{n}\left(y_{i t} \mid \mathbf{x}_{i t}, \boldsymbol{\theta}^{n}, c_{i}\right)$ and $f^{a}\left(y_{i t} \mid \mathbf{x}_{i t}, \boldsymbol{\theta}^{a}, c_{i}\right)$ denote the corresponding densities of outcome $y_{i t}$. Then, the following overall density defines a two-component finite mixture for the two groups of affiliates

$$
\begin{aligned}
f\left(y_{i t} \mid \mathbf{x}_{i t}, \boldsymbol{\theta}^{a}, \boldsymbol{\theta}^{n}, c_{i}, \pi^{n}\right) & =\pi^{n} f^{n}\left(y_{i t} \mid \mathbf{x}_{i t}, \boldsymbol{\theta}^{n}, c_{i}\right) \\
& +\left(1-\pi^{n}\right) f^{a}\left(y_{i t} \mid \mathbf{x}_{i t}, \boldsymbol{\theta}^{a}, c_{i}\right) .
\end{aligned}
$$

While $\pi^{\ell}$ is unknown, it can be estimated along with the parameters we are interested in, $\boldsymbol{\theta}^{\ell}$. In principle, we could treat the probability $\pi^{n}$ of belonging to the group of non-avoiding affiliates as an unknown constant. But since we observe characteristics of the affiliates which should influence

\footnotetext{
${ }^{7}$ Heckman and Singer (1984) introduced finite mixture models for cross-sectional data. Only few studies have applied such models with panel data (see, Bago d'Uva, 2005, 2006, and Deb and Trivedi, 2011, for exceptions). In this paper, we account for affiliate-specific unobserved effects by modeling the conditional mean of the unobserved effects following the approach of Mundlak (1978) as popularized by Chamberlain (1984) and Wooldridge (2002).
} 
that probability according to economic theory, we may parameterize $\pi^{n}$ by, e.g., a logistic function of observable characteristics. For this, let us write

$$
\pi^{n}=\frac{\exp \left(\mathbf{z}_{i t}^{\prime} \boldsymbol{\delta}\right)}{\left[1+\exp \left(\mathbf{z}^{\prime}{ }_{i t} \boldsymbol{\delta}\right)\right]},
$$

where $\mathbf{z}_{i t}$ is a $Q \times 1$ vector of observed determinants of the probability of being able to avoid taxes and $\boldsymbol{\delta}$ a $Q \times 1$ vector of parameters to be estimated.

Furthermore, we specify the density $f^{\ell}\left(y_{i t} \mid \boldsymbol{\theta}^{\ell}\right)$ as a negative binomial ${ }^{8}$ The estimation is performed by maximum likelihood. For details on the functional specification of the model, see the Appendix.

The posterior probability that observation $y_{i t}$ belongs to the group of non-avoiders is given by

$$
\operatorname{Pr}\left(y_{i t} \in n\right)=\frac{\pi^{n} f^{n}\left(y_{i t} \mid \mathbf{x}_{i t}, \boldsymbol{\theta}^{n}, c_{i}\right)}{\pi^{n} f^{n}\left(y_{i t} \mid \mathbf{x}_{i t}, \boldsymbol{\theta}^{n}, c_{i}\right)+\left(1-\pi^{n}\right) f^{a}\left(y_{i t} \mid \mathbf{x}_{i t}, \boldsymbol{\theta}^{a}, c_{i}\right)} .
$$

Hence, equation (6) permits classifying a posteriori the observations (affiliates and years) into the groups.

\subsection{Data and Specification}

For an analysis of tax avoidance as suggested, it appears vital to employ high-quality data with two characteristics. First, the covered firms should be comparable MNEs that - from a home-country perspective - all operate under the same system of taxation (tax exemption in case of Germany). Second, selectivity regarding the coverage of foreign affiliates across host countries should be avoided. If one of the two requirements were violated, we would run at risk to obtain biased results regarding the scope of tax avoidance in the data. Notice that lack of comparability and selectivity are an issue in most aggregate data-sets and even in firm-level data-sets $9^{9}$ but they are met in the Census-type data we are able to employ for Germany. We use

\footnotetext{
${ }^{8}$ By choosing a negative binomial model, we allow for unobserved heterogeneity within each subpopulation (or latent class). Data on fixed assets of foreign affiliates clearly display over-dispersion (see Table 1) which calls for distributional assumptions that are consistent with the negative binomial model. However, this seems to apply also for other activities of firms abroad. For instance, Eaton, Kortum, and Sotelo (2011) recently employ a negative binomial model to explain firm-level exports.

${ }^{9}$ For instance, aggregate data-sets provided by the OECD or UNCTAD are based on source country data which underly different reporting requirements. Hence, an analysis of the tax responsiveness of direct investment and other activities of MNEs may in part
} 
the Microdatabase Direct Investment (MiDi) provided by Deutsche Bundesbank (the German Central Bank; see Lipponer, 2009, for a documentation). This data-set, which can be used exclusively on site at the Bank's Research Center, contains annual statistics on virtually all foreign affiliates of German MNEs. All German investors holding $10 \%$ or more of shares or voting rights in foreign firms with a balance-sheet total of more than 3 million Euros are required by law to report to Deutsche Bundesbank balance-sheet information as well as information on the sector, legal form, and number of employees of their foreign affiliates 10 Indirect participating interests are to be reported whenever residents hold more than $50 \%$ in a foreign firm and these dependent enterprises themselves hold $10 \%$ or more of the shares or voting rights in other foreign enterprises ${ }^{11}$

The underlying data-set comprises 30,647 foreign affiliates of 8,369 German MNEs investing in 103 countries at an annual basis over the period 1999 to 2010. Altogether, there are 171,617 observations on the stock of fixed assets of these foreign affiliates. Since we employ lagged values of affiliatespecific variables in our regressions (implying that one year of observations is lost), the actual number of observations, affiliates and years is lower (see Tables 1 to 7 below).

We are predominantly interested in the effect of the host country statutory corporate income tax rate the foreign affiliate $i$ is located in, CITR $R_{i t}$, on the fixed assets of foreign affiliates, where $t$ denotes the year. As two alternative tax measures, we use the effective average tax rate, $E A T R_{i t}$, which measures to which extent total profits of an investment project (with a given profitability) are taxed on average, and the effective marginal tax rate, $E M T R_{i t}$, which measures the tax on a marginal investment project that just earns the cost of capital. Both measures consider rules determining the tax base (such as depreciation allowances). Previous work suggests that the $E A T R_{i t}$ is the relevant tax measure for discrete (lumpy) investment de-

reflect a correlation between tax and activity levels with reporting thresholds across parent or host countries. Firm-level data-sets based on survey data such as Bureau van Dijk's AMADEUS or ORBIS databases could principally be used, but ownership information is measured with much error and so is the classification of firms as MNEs or foreign affiliates; moreover, such databases face a substantial heterogeneity in the degree of firm coverage across parent and host countries.

${ }^{10}$ The reporting requirements are set by the Foreign Trade and Payments Regulation. Reporting thresholds have been changed in the past. See Lipponer (2009) for details.

${ }^{11}$ As of 2007 , indirect participating interests are to be reported whenever the dependent enterprise held by the German investor holds $50 \%$ or more of the shares or voting rights in other foreign enterprises. 
cisions and location choices (Devereux and Griffith, 1998, 2003), whereas the $E M T R_{i t}$ is relevant for marginal investment decisions. However, EATR and $E M T R_{i t}$ are only available for a subset of countries in the sample, leading to a loss of 33,865 observations. For this reason, we use $C I T R_{i t}$ in our preferred specification $\sqrt{12}$ In any case, we expect a higher corporate profit tax rate to raise the cost of capital and affect investment in fixed assets negatively to the extent that a foreign affiliate is unable to avoid taxation by, for instance, shifting profits.

The identification of the two population components (non-avoiders and avoiders ) - and thus of the differential tax effects - relies on differences across components in the distributional moments of the dependent variable. Accordingly, it is important to control for affiliate characteristics that explain differences in the level of fixed assets beyond taxes. We therefore include a number of covariates in the vector $\mathbf{x}_{i t}$. The theory of MNEs and trade suggests that MNE activity depends on market size, skilled labor endowments, capital-labor ratios, factor prices, and trade and investment costs (see Carr, Markusen, and Maskus, 2001; Markusen, 2002; Markusen and Maskus, 2002; Bloningen, Davies, and Head, 2003; Bergstrand and Egger, 2007; and Blonigen and Piger, 2010). This motivates the choice of the following variables in $\mathbf{x}_{i t}$.

To capture market size, we include $G D P_{i t}$, the log of real GDP in the market affiliate $i$ is located in and year $t$. The log capital-labor ratio, $K L R A T_{i t}$, and the tertiary school enrolment rate, $S K I L L_{i t}$, reflect relative factor endowments in affiliate $i$ 's market in year $t$. The log of real GDP per capita, $G D P P C_{i t}$, is a proxy for labor productivity. The local lending interest rate, $L E N D_{i t}$, and inflation rate, $I N F L_{i t}$, reflect capital costs. We also include a corruption perception index, $C P I_{i t}$, and a measure of financial freedom or banking efficiency, FINFR $R_{i t}$, to control for investment costs in $i$ 's market and year $t$. Trade costs are usually assumed to be fixed over a short time span as ours and are captured in our application (along with all other time-invariant factors) by the affiliate-specific fixed effect $c_{i}$. To the extent that $G D P_{i t}$ and $G D P P C_{i t}$ reflect general market size and income as well as factor abundance conditions in $i$ 's market in year $t$, it appears desirable to include measures which are capable of reflecting such conditions at the

\footnotetext{
${ }^{12}$ Devereux and Griffith (2003) point out that the effective average tax rate is a weighted average of the effective marginal tax rate and the statutory tax rate, and it converges to the latter as profits rise. Buettner and Ruf (2007) and Overesch and Wamser (2009, 2010) illustrate that the statutory corporate income tax rate is an appropriate alternative to effective tax measures.
} 
level of the affiliate rather than the host country only. We therefore include the one-period-lagged log of foreign affiliate sales, $S A L E S_{i t-1}$, and the one-period-lagged log of employees, $E M P_{i t-1}$, as two additional regressors. Results without these two subsidiary-specific variables are discussed in the context of a sensitivity analysis below.

The vector $\mathbf{z}_{i t}$ includes the following variables as determinants of the probability of affiliate $i$ being a tax avoider. NSI $S_{i t}$ is the number of enterprises (foreign entities included in our data-set) that are affiliated with $i$ but reside in other countries. Certainly, we would expect profit shifting incentives and opportunities to rise with a larger foreign affiliate network as captured by $N S I S_{i t}$. We also employ the internal-debt-to-capital ratio $I D R_{i t}$. We would associate a higher level of $I D R_{i t}$ as to be indicative of profit shifting by way of debt shifting (see, e.g., Desai, Foley and Hines, 2004a; Egger, Keuschnigg, Merlo and Wamser, 2014). Moreover, we include the ownership share of the MNE in the foreign entity, $O S_{i t}$. Desai, Foley, and Hines (2004b) point out that whole ownership facilitates worldwide tax planning, while partial ownership is associated with coordination costs. Following this argument, we would expect profit shifting to be more likely in wholly-owned than in partially-owned foreign affiliates. $R \& D_{i t}$ is a binary indicator variable indicating whether the affiliate operates in the $R \& D$-intensive sector or not. With respect to $R \& D_{i t}$, Grubert (2003) points out that R\&D-intensive affiliates have better opportunities to shift profits compared to others, since they are involved in a wider range of intra-firm transactions. $A T A X_{i t}$ captures the affiliate-specific tax incentive to shift profits relative to the other entities of the MNE. It is defined as the average tax rate applicable at other locations an MNE is active in, where also the tax at the German parent is accounted for. Obviously, the incentive to shift profits to other locations increases as $A T A X_{i t}$ declines. Hence, we expect $A T A X_{i t}$ to have a negative effect on the propensity of tax avoidance. Similar to Huizinga, Laeven, and Nicodème (2008), the tax incentives arising at other locations might also be weighted with the total assets of the respective entity to capture the size (or importance) of that entity. For this purpose, we define

$$
A T A X W_{i t}=\sum_{m \neq i} \frac{T A_{m t} \tau_{m t}}{\sum_{m \neq i} T A_{m t}},
$$

where $T A_{m t}$ are the total assets of affiliate $m$ and $\tau_{m t}$ is the corporate tax rate applicable to affiliate $m \neq i$. Note that we can not consider the German parent in the calculation of $A T A X W_{i t}$ since information on total assets for the parent is not available in our data. 
Furthermore, we use the binary indicator variable $S I_{i t}$, which is unity if affiliate $i$ is the only affiliate of a given MNE observed in our data and zero else. Apart from $O S_{i t}$, we use two binary indicator variables in $\mathbf{z}_{i t}$ to capture ownership information. First, $W O_{i t}$ indicates whether the German parent wholly-ownes affiliate $i$ in year $t$ or not (see Weichenrieder, 2009). Second, $M O_{i t}$ indicates whether affiliate $i$ is majority-owned by the parent in year $t$. To be specific, $W O_{i t}$ and $M O_{i t}$ take value 1 if the foreign entity is wholly or majority owned, and zero otherwise. Finally, we use the fractional variable $S H D E_{i t}$, which indicates to which extent countries restrict internal debt usage for profit-shifting purposes. Many countries define specific debtto-equity ratios known as thin-capitalization rules, up to which interest is fully deductible. If the debt-to-equity ratio exceeds this threshold, interest is no longer tax-deductible and fully taxed. If debt usage is unrestricted, $S H D E_{i t}=1$. In the hypothetical case that interest deduction is generally denied, $S H D E_{i t}=0$. For that reason, $S H D E_{i t}$ is often called the safe-haven ratio. For more details on thin-capitalization rules and the definition of safe haven ratios, see Buettner, Overesch, Schreiber, and Wamser (2012).

- Insert Table 1 here -

Table 1 provides information about the mean, the standard deviation, and the data sources for all variables employed.

\section{$5 \quad$ Results}

\subsection{Benchmark Results}

Table 2 presents results for two-component negative binomial mixture models for the effects of corporate taxes on the fixed assets of foreign affiliates. We find that the tax responses differ significantly across components which are associated with tax avoiders and non-avoiders. Across all specifications, we identify a larger component (fraction of firms) associated with non-avoiders of profits which have a lower conditional mean for fixed assets and react (highly) significantly to tax rates, and a smaller one associated with avoiders that have a higher average level of fixed assets, which are not significantly affected by corporate profit taxation ${ }^{13}$ The estimated tax coefficient refers to a

\footnotetext{
${ }^{13}$ The estimated coefficients of both components are obtained simultaneously through maximum likelihood estimation using the whole sample.
} 
(semi-)elasticity, which implies that a 1-percentage point tax increase reduces investment in fixed assets by about $0.85 \%$ in case of the non-avoiders ${ }^{14}$ After each of the following specifications we test whether tax coefficients can be statistically distinguished from each other and find that the null hypothesis of equal parameters can always be rejected on a $5 \%$ level ${ }^{15}$ As for the other control variables, non-avoiders and avoiders respond in a fairly similar way. However, the avoiders are not only irresponsive with respect to taxes but also with respect to $F I N F R_{i t}$ (financial freedom or banking efficiency). This is interesting, as it is in line with arguments supporting the view that MNEs can avoid adverse local capital market conditions by drawing on financing provided through an internal capital market (Desai, Foley and Hines, 2004a; Egger, Keuschnigg, Merlo and Wamser, 2014). Note also that, conditional on the two variables that vary at the affiliate level, it seems plausible that many of the country controls are not statistically significant. We will come back to the discussion of the specific effects of different regressors below 16

\section{- Insert Tables 2 to 5 here -}

We let the probability of profit-tax non-avoiding depend on observable characteristics collected in $\mathbf{z}_{i t}$ in terms of the above notation. Tables 2,5 show

\footnotetext{
${ }^{14}$ In any model with an exponential conditional mean $E(y \mid \mathbf{x})=\exp \left(\mathbf{x}^{\prime} \beta\right)$, the regression coefficients can be interpreted as elasticities (of variables in logs) or semi-elasticities (of other variables) since the marginal effect of the $k$ th regressor is $M E_{k}=E(y \mid \mathbf{x}) \times \beta_{k}$, so that $\beta_{k}=M E_{k} / E(y \mid \mathbf{x})$ (see Cameron and Trivedi, 2005).

${ }^{15}$ This result holds also for the sensitivity analysis and the alternative tax measures presented in Table 7

${ }^{16}$ We may compare these results to estimates from a simple negative binomial regression, which disregards the possibility of latent components in the population of foreign affiliates associated with tax avoidance (results are available upon request). There, we estimate a negative but insignificant impact of $C I T R_{i t}$. However, earlier research using a smaller sample of firms from the same data source and similar regression techniques did find significant corporate profit tax effects. For instance, Egger and Merlo (2011) find a significant tax effect on the fixed assets at the parent firm level in a poisson regression including only 6,915 parent firms in 51 host countries and excluding indirectly-held affiliates. While the exclusion of indirectly-held affiliates was necessary in that research, we explicitly want to include indirectly-held units here. Note that the positive (though insignificant) coefficient of the avoiders is consistent with the results presented in Wamser (2011). This paper shows (theoretically and empirically) that indirectly-held foreign affiliates may make use of a double interest deduction associated with internal debt financing, so that a tax-paradox situation may arise and an increase in taxes reduces the required rate of return. Hence, a higher tax is, ceteris paribus, associated with an expansion of investments at the margin.
} 
different models which differ in the specification of the tax-non-avoidance probability (i.e., in the variables included in $\mathbf{z}_{i t}$ ). The respective characteristics used in the probability specifications are listed in the rows below $\operatorname{Pr}($ Non-avoiders). In Table 2, this probability depends on NSIS $i t$ (the number of affiliated enterprises in other countries of affiliate $i$ in $t), I D R_{i t}$ (the internal-debt-to-capital ratio of affiliate $i$ in $t$ ), $O S_{i t}$ (the ownership share of the German firm in affiliate $i$ in $t$ ), and a constant, respectively.

An increase in the number of affiliated entities significantly raises the probability of being an avoiding entity. This is in line with what we would expect, as a larger group (more foreign affiliates) raises the opportunities for tax avoidance.

Consistent with expectations, a higher internal-debt-to-asset ratio $I D R_{i t}$ lowers the probability of being a non-avoider. Only the ownership share $O S_{i t}$ has no significant impact on the probability of non-avoiding. Notice that the results of that model are largely similar in general terms to the one which models the probability of non-avoiding by a constant only (the estimates are suppressed but are available upon request). Using the calculated posterior probability of belonging to that group according to equation (6), we can estimate the percentage of avoiders and non-avoiders, respectively. For example, using the specification with $N S I S_{i t}, 89.88 \%$ of the affiliate-year observations are classified as avoiders and $10.12 \%$ as non-avoiders.

In Tables 3, 4, and 5, we assess to which extent different specifications of the probability of non-avoiding profit taxes affect the results. First, if a foreign entity is active in the $R \& D$ sector, the probability of being a nonavoider is lower. This effect is, however, not significant. Second, a higher average tax at the other locations where the firm is operating entities does not have a significant impact either. Third, once the tax incentives arising from other locations are weighted with the size of the operation there $\left(A T A X W_{i t}\right)$, we find that a higher (weighted) average tax level within the firm raises the probability of being a non-avoider. As $A T A X W_{i t}$ is bigger if no entities in low-tax or tax-haven countries are operated, this is what we would expect. Fourth, if entity $i$ is the only foreign entity operated by the firm $\left(S I_{i t}=1\right)$, it is more likely to be a non-avoider. The positive impact of $S I_{i t}$ is in line with the negative impact of $N S I S_{i t}$, where $S I_{i t}=1$ includes by definition all cases with $N S I S_{i t}=0$. Fifth, while we estimate a significant negative impact of majority-ownership $M O_{i t}$ on the probability of being a non-avoider, the parameter estimate for whole-ownership $\left(W O_{i t}\right)$ is insignificant. The former result is in line with arguments about facilitated tax planning (see Desai, Foley, and Hines, 2004b). Sixth, if a country imposes a relatively lax thin- 
capitalization rule, reflected in a higher value of $S H D E_{i t}$, the probability of German foreign affiliates to be assigned to the avoiders is bigger, as expected.

Our preferred model is Specification XI in Table 5. There, we include all variables used in Specifications I-X except for $W O_{i t}, M O_{i t}$, and $A T A X_{i t}$ (since these are fully or mostly captured by $O S_{i t}$ and $A T A X W_{i t}$ ). We will compare this specification with the other ones below. What we can confirm at this point is that the tax effects for the groups of avoiders and non-avoiders are relatively stable: there is a negative and statistically significant effect of taxes for the majority of foreign affiliates classified as non-avoiders; there is a statistically insignificant effect of taxes for the smaller group of foreign affiliates classified as avoiders.

A comparison of the a-posteriori assignment of affiliates and years to the two groups across different tax-non-avoidance probability specifications in Tables 2- 5 obtains the following insights. The share of avoiders amounts to $10.12 \%$ (I), $9.92 \%$ (II), $10.27 \%$ (III), $9.87 \%$ (IV), $9.89 \%$ (V), $9.83 \%$ (VI), $9.87 \%$ (VII), $10.14 \%$ (VIII), $10.23 \%$ (IX), $9.84 \%$ (X), and $11.08 \%$ (XI), where specification numbers are referred to in parentheses. Clearly, the share assigned to the avoiders is highest for Specification XI. 2,095 affiliates are always (over all 11 specifications and years) assigned to the avoiders, and 21,714 affiliates are always assigned to the non-avoiders, irrespective of the specification. 1,623 are always classified (across all 11 specifications) as "partial users", meaning that their assignment changes at least once over the years within a given specification. For only 1,622 observations (or only 6\%), the assigned class differs across specifications. Hence, the classification is quite robust 17

With respect to the parameters of the variables other than $C I T R_{i t}$ in $\mathbf{x}_{i t}$, non-avoiders do not differ much from avoiders. Similar to $C I T R_{i t}$ (the statutory profit tax rate), FINFR $R_{i t}$ (financial freedom or banking efficiency) is only significantly related to the fixed assets for the group of non-avoiders. The estimates for both $L E N D_{i t}$ and $I N F L_{i t}$ (lending interest rate and inflation rate) point in the same direction, as both variables tend to exert negative and statistically significant impacts only on the non-avoiders. All this is in line with arguments supporting the view that larger MNEs maintain internal capital markets and can avoid adverse credit market conditions (Desai, Foley and Hines, 2004a). Both $S A L E S_{i t-1}$ and EMP $P_{i t-1}$ (sales and employment

\footnotetext{
${ }^{17}$ Another interesting result is that the average number of affiliates classified as avoiders per MNE is constantly increasing over time. We obtain this result by running a regression of the share of avoiders per MNE on time dummies and MNE fixed effects.
} 
in period $t-1$ ) have a positive and statistically significant effect on the size of fixed assets for both groups of firms, as expected. After controlling for those variables, the market size of the host country as measured by $G D P_{i t}$ does not display a significant effect on the level of fixed assets. The variable $S K I L L_{i t}$ (skilled labor abundance) exerts a positive impact on investment in most specifications, the variable $K L R A T_{i t}$ (capital labor ratio) is negatively related to investment in case of the non-avoiders and insignificant in case of the avoiders. GDPPC $C_{i t}$ (per-capita income) enters usually positively and statistically significantly for the avoiders and insignificantly for the nonavoiders. To the extent that $G D P P C_{i t}$ proxies for labor productivity, this is consistent with a prevalence of (large-)market-seeking horizontal MNEs - producing the same product at the home and the host market - among the non-avoiders, and a greater presence of low-cost-seeking vertical MNEs producing labor-intensive intermediate goods among the avoiders. Given that vertically-integrated firms may have more opportunities to shift profits through transfer pricing than horizontally-organized foreign affiliates, consistent with expectations. Finally, a lower level of perceived corruption $\left(C P I_{i t}\right)$ positively affects fixed assets held by the non-avoiders.

$$
\text { - Insert Table 6 and Figures } 1 \text { to } 4 \text { here - }
$$

As shown above, we may now use the predicted posterior probability of belonging to either component to classify the individual observations into avoiders and non-avoiders ${ }^{18}$ Table 6 reports the means of the dependent and explanatory variables for each component after splitting the sample according to the predictions of the preferred Specification XI. The firms classified as avoiders invest an average amount of 119.7 million Euros in fixed assets, while the non-avoiders have an average investment of just 10.9 million Euros. Even though they account for only $11.08 \%$ of the units in the sample, avoiders account for about $58 \%$ of the total stock of fixed assets held abroad by German MNEs. Avoiders have on average 36 affiliated enterprises of the same parent in other countries, while non-avoiders have only about 25 . The country-specific explanatory variables, especially the tax measures, do not display a significant difference across groups. Note that the reported number of affiliates and also the number of parent firms in Table 6 include what we have called "partial users" above.

\footnotetext{
${ }^{18}$ Affiliates are assigned to a group when the posterior probability of belonging to that group is higher than $50 \%$. Although this is a standard approach of how to classify observations, we have used some alternative cutoffs. Deviation from the $50 \%$ cutoff does not lead to different conclusions, however.
} 
From the last two columns of Table 5 we know that the means of the predicted values of fixed assets amount to 9.6 and 67.8 for non-avoiders and avoiders, respectively. Figure 1 shows the predicted mixture densities, and reveals that the estimated component distributions overlap in a wide range of values. This highlights the fact that the finite mixture model captures latent heterogeneity and improves the assessment of differential tax responses that could be made relying only on a mere grouping of firms according to their investment levels.

Figures 2 to 4 show fixed assets, sales, and employment by quintiles of the distribution of the corporate tax rate for non-avoiders and avoiders. In all figures, the upper graph shows average values and the lower graph shows percentages of the total values accounted for by each of the two groups. The upper graph of Figure 2 reveals that the differences between average levels of fixed assets of non-avoiders versus avoiders are significant, irrespective of the level of the tax rate. The avoiders seem to invest the most, on average, in high-tax countries: the lower graph suggests that they account for about $60 \%$ of total investments in fixed assets in those countries. This is consistent with the finding of a relative insensitivity to profit tax rates for those firms. Figures 3 and 4 show that avoiders also display higher average sales and numbers of employees than non-avoiders (particularly in high-tax countries), but non-avoiders together account for about $80 \%$ of the sales and employment, respectively.

Compared with Figure 2, Figures 3 and 4 reveal that profit tax avoiders and non-avoiders differ much less strongly by their size in terms of foreign affiliate sales or employment than in terms of fixed assets. The total contributions of avoiders and non-avoiders to aggregate foreign affiliate sales and employment across all German-held affiliates correspond roughly to their relative numbers in the estimation sample: approximately $90 \%$ for non-avoiders and $10 \%$ for avoiders. Note that this is important for conclusions concerning tax policy. These results indicate that anti-profit-shifting policy measures might have a relatively stronger impact on the allocation of fixed assets than on sales or employment, unless they stimulate foreign affiliate relocation to a sizable extent.

Overall, we find evidence for two different groups of firms which react differently to corporate taxation. The larger group of firms is unable to avoid taxes and is negatively affected by the corporate tax rate in terms of FDI. In our preferred specification, the estimated tax semi-elasticity for the group of non-avoiders is about -0.81 . Hence, a one-percentage-point increase in the statutory tax rate is associated with a decrease by $0.8 \%$ in the stock 
of fixed assets of a non-avoiding foreign affiliate in that country. The smaller group of is able to avoid taxation and does not show a significant response to the corporate profit tax rate. We can quantify that effect by evaluating it at the sample mean of the component (see Table 6). The average affiliate classified as a non-avoider invests about 10.978 million Euros in fixed assets. Such an affiliate would reduce its investment in fixed assets by about 88,922 Euros in response to a one-percentage-point increase in the corporate tax rate. We may ask what would happen if countries were broadening the tax base and close tax loopholes or prevent tax avoidance by MNEs. Under the assumption that avoiders could no longer avoid corporate profit taxes and would face the same tax elasticity as the non-avoiders, the implied effect given the average investment size of the avoiders of about 119.672 million Euros would be a reduction of investments by almost 1 million Euros per percentage-point of a profit tax increase.

\subsection{Sensitivity Analysis}

Table 7 presents alternative specifications. Specification XII uses the effective average tax rate $\left(E A T R_{i t}\right)$ as an alternative corporate profit tax measure to the statutory rate $\left(C I T R_{i t}\right)$. The results remain unchanged: the tax effect is negative and significant for non-avoiders with the lower conditional mean of fixed assets, and insignificant for avoiders with the higher mean of fixed assets. Given that we lose observations when using $E A T R_{i t}$ instead of $C I T R_{i t}$, we prefer the original specification in Table 5.

- Insert Table 7 here -

Specification XIII in the same table employs the effective marginal tax rate $\left(E M T R_{i t}\right)$ instead of the statutory tax rate. Again, we can confirm the basic finding that only the non-avoiders respond to the marginal tax rate. Specification XIV, finally, reports results where the affiliate-specific variables $S A L E S_{i t-1}$ and $E M P_{i t-1}$ are excluded from a specification that otherwise is the same as Specification XI. There, estimated tax coefficient for the non-avoiders is somewhat larger than in Specification XI. Disregarding any affiliate-level determinants seems extreme, though 19

\footnotetext{
${ }^{19}$ We also estimated models where we used contemporaneous values of the affiliatespecific variables. The results, available upon request, are very similar to those of Specification XI.
} 
Furthermore, we estimated mixture models with more than two components. It turns out that models with, e.g., three or four components have much weaker convergence properties than the proposed model with two components for tax avoiders and non-avoiders. The reason for this property is that enforcing more than two components leads to largely overlapping groups within two broader classes of groups that correspond to the identified ones in the proposed two-component framework. For instance, a three-component mixture model identifies one component (about $73 \%$ of the sample) where affiliates react negatively and statistically significantly to the tax rate, one where the tax response is negative but insignificant, and one smaller component where the tax response is positive and statistically insignificant (about $8 \%$ of the sample). The estimated tax semi-elasticities for the first group (the non-avoiders) amounts to - 0.95 . However, the two groups together with a negative tax responsiveness are quite similar (with overlapping confidence intervals) so that, after controlling for affiliate-specific sales and employment, the likelihood function to be optimized is quite flat. This problem is aggravated as one specifies models with even more components. Taken together, this provides implicit evidence in favor of the two-component mixture model of tax avoiders and non-avoiders due to a large degree of similarity of the moments of the distributions of firms within those groups.

\section{Conclusions}

This paper investigates the tax responsiveness of MNEs' investment decisions in foreign countries, distinguishing firms that are avoiders of profit taxes from those that are non-avoiders. From a theoretical point of view, the tax responsiveness of firms crucially depends on this distinction. Empirically, however, whether or not a firm is able to avoid profit taxes is unobservable.

The paper employs a finite mixture model to distinguish the tax responsiveness of investments made by foreign affiliates which are able to avoid taxes and reduce their tax base from that of affiliates which are not able to do so and are thus fully taxed. Using a panel of 27,054 foreign affiliates of German MNEs over the years 1999 to 2010, we show that, while avoiders do not respond to host-country taxes at all, taxes significantly affect investment decisions of non-avoiders. The identified non-avoiders are estimated to be the larger group of firms (about $89 \%$ of the sample) while there are fewer avoiders. However, avoiders are larger than non-avoiders in terms of their fixed assets. The estimated effect of a one-percentage-point increase in the 
corporate profit tax rate for non-avoiders amounts to $-0.81 \%$ in terms of fixed assets, or 88,922 Euros, for the average affiliate.

If tax avoidance could be made impossible, the implied effect of a onepercentage-point increase in profit taxes in Euros would ceteris paribus be many times higher. Suppose tax avoidance would be impossible so that the profit tax semi-elasticity were ceteris paribus the same for tax avoiders as for non-avoiders. Then, we would obtain a weighted profit tax semi-elasticity corresponding to $-0.81 \% \cdot 0.89=-0.72 \%$, where $-0.81 \%$ is the unweighted semi-elasticity for non-avoiders in response to a on-percentage-point increase in the corporate profit tax rate and 0.89 is the fraction of non-avoiders in the data. When using fixed asset shares rather than frequency shares as the weight, the corresponding average weighted profit tax semi-elasticity would amount to $-0.81 \% \cdot 0.42=-0.34 \%$. When pooling all parameters across avoiders and non-avoiders in the data, the common profit tax semi-elasticity is estimated to not be significantly different from zero. Hence, not distinguishing between avoiders and non-avoiders leads to a downward bias of the estimated responsiveness of the sensitive tax base and, hence, of profit tax revenues.

The consequences for a given country from introducing measures to prevent tax avoidance will depend on the composition of affiliates investing in that country. A considerable but varying proportion of a country's foreign investments are carried out by firms that shift profits. Preventing tax avoidance (or, in particular, profit shifting in the context of MNEs) would ceteris paribus raise profit tax revenues. However, assets and affiliates of profit avoiders are mobile across international borders. Hence, the adoption of a policy to restrict tax avoidance opportunities would expose countries to tax competition with other countries over currently shifting firms' investments. If all countries started to fight tax avoidance or profit shifting in an uncoordinated way, many of them would have to lower corporate profit tax rates in order to prevent a significant relocation of plants and capital of investment projects from their jurisdictions. In particular, countries which currently host large fractions of avoiders (or their fixed assets) would have an inclination towards such a policy. 


\section{References}

Aitkin, M., and D. B. Rubin (1985), Estimation and Hypothesis Testing in Finite Mixture Models, Journal of the Royal Statistical Society 47, $67-75$.

Bago d'Uva, T. (2005), Latent Class Models for Use of Primary Care: Evidence from a British Panel, Health Economics 14, 873-892.

Bago d'Uva, T. (2006), Latent Class Models for Utilisation of Health Care, Health Economics 15, 329-343.

Barrios, S., H. Huizinga, L. Laeven, and G. Nicodème (2008), International Taxation and Multinational Firm Location Decisions, Journal of Public Economics 96(11-12), 946-958.

Becker, S.O., P.H. Egger, and V. Merlo (2009), How Low Business Tax Rates Attract Multinational Headquarters: Municipality-Level Evidence from Germany, Journal of Public Economics 96(9-10), 698-711.

Bergstrand, J.H., and P.H. Egger (2007), A Knowledge-and-Physical-Capital Model of International Trade, Foreign Direct Investment, and Foreign Affiliate Sales: Developed Countries, Journal of International Economics 73, 278-308.

Blonigen, B.A., R.B. Davies, and K. Head (2003), Estimating the Knowledgecapital Model of the Multinational Enterprise: Comment, American Economic Review 93, 980-994.

Bloningen, B.A., and J. Piger (2010), Determinants of Foreign Direct Investment, NBER Working Paper No. w16704.

Bucovetsky, S., and A. Haufler (2008), Tax Competition when Firms Choose their Organizational Form: Should Tax Loopholes for Multinationals be Closed?, Journal of International Economics 74, 188-201. 
Buettner, T., M. Overesch, U. Schreiber, and G. Wamser (2012), The Impact of Thin-Capitalization Rules on the Capital Structure of Multinational Firms, Journal of Public Economics 96, 930-938.

Buettner, T., and M. Ruf (2007), Tax Incentives and the Location of FDI: Evidence from a Panel of German Multinationals, International Tax and Public Finance 14, 151-164.

Buettner, T., and G. Wamser (2012), Internal Debt and Multinationals' Profit Shifting Empirical Evidence from Firm-Level Panel Data, $\mathrm{Na}$ tional Tax Journal 66, 63-95.

Cameron, C.A., and P.K. Trivedi (2005), Microeconometrics Methods and Applications, Cambridge University Press, Cambridge, MA.

Carr, D.L., J.R. Markusen, and K.E. Maskus (2001), Estimating the KnowledgeCapital Model of the Multinational Enterprise, American Economic Review 91, 693-708.

Chamberlain, G. (1984), Panel Data, in Handbook of Econometrics, ed. by Z. Griliches and M.D. Intriligator, vol. 2, 1247-1318. North Holland, Amsterdam.

Clausing, K.A. (2003), Tax-motivated Transfer Pricing and US Intrafirm Trade Prices, Journal of Public Economics 87, 2207-2223.

De Mooij, R.A., and S. Ederveen (2003), Taxation and Foreign Direct Investment: A Synthesis of Empirical Research, International Tax and Public Finance 10, 673-693.

De Mooij, R.A., and S. Ederveen (2006), What a Difference Does it Make? Understanding the Empirical Literature on Taxation and International Capital Flows, European Commission Economic Paper No. 261. 
De Mooij, R.A., and S. Ederveen (2008), Corporate Tax Elasticities: A Readers Guide to Empirical Findings, Oxford Review of Economic Policy 24, 680-697.

Deb, P., and P.K. Trivedi (2011), Finite Mixture for Panels with Fixed Effects, Hunter College Working Paper.

Desai, M.A., C.F. Foley, and J.R. Hines (2004a), A Multinational Perspective on Capital Structure Choice and Internal Capital Markets, The Journal of Finance 59, 2451-2487.

Desai, M.A., C.F Foley, and J.R. Hines (2004b), The Costs of Shared Ownership: Evidence from International Joint Ventures, Journal of Financial Economics 73, 323-374.

Devereux, M., and R. Griffith (1998), Taxes and the Location of Production: Evidence from a Panel of US Multinationals, Journal of Public Economics 68, 335-367.

Devereux, M., and R. Griffith (2003), Evaluating Tax Policy for Location Decisions, International Tax and Public Finance 10, 107-126.

Eaton, J., S. Kortum, and S. Sotelo (2011), International Trade: Linking Micro and Macro, unpublished manuscript, University of Chicago.

Egger, P.H., W. Eggert, C. Keuschnigg, and H. Winner (2010), Corporate Taxation, Debt Financing and Foreign-plant Ownership, European Economic Review 54, 96-107.

Egger, P., C. Keuschnigg, V. Merlo, and G. Wamser (2014), Corporate Taxes and Internal Borrowing within Multinational Firms, American Economic Journal: Economic Policy 6(3), 54-93.

Egger, P.H., W. Eggert, and H. Winner (2010), Saving Taxes Through Foreign Plant Ownership, Journal of International Economics 81, 99108. 
Egger, P.H., and V. Merlo (2011), Statutory Corporate Tax Rates and Double Taxation Treaties as Determinants of Multinational Firm Activity, FinanzArchiv, 67(2), 145-170.

Grubert, H. (2003), Intangible Income, Intercompany Transactions, Income Shifting, and the Choice of Location, National Tax Journal 56, 221-242.

Grubert, H., and J. Mutti (1991), Taxes, Tariffs and Transfer Pricing in Multinational Corporate Decision Making, The Review of Economics and Statistics 73, 285-293.

Haufler, A., and M. Runkel (2010), Firms' Financial Choices and Thin Capitalization Rules under Corporate Tax Competition, European Economic Review 56(6), 1087-1103.

Heckman, J.J., and B. Singer (1984), A Method for Minimizing the Impact of Distributional Assumptions in Econometric Models for Duration Data, Econometrica 52, 271-320.

Hines, J.R. (1996), Altered States: Taxes and the Location of Foreign Direct Investment in America, American Economic Review 86, 1076-1094.

Hines, J.R. (1999), Lessons from Behavioral Responses to International Taxation, National Tax Journal 52, 305-322.

Hines, J.R., and E.M. Rice (1994), Fiscal Paradise: Foreign Tax Havens and American Business, Quarterly Journal of Economics 109, 149-182.

Huizinga, H., and L. Laeven (2008), International Profit Shifting Within Multinationals: A Multi-country Perspective, Journal of Public Economics 92, 1164-1182.

Huizinga, H., L. Laeven, and G. Nicodème (2008), Capital Structure and International Debt Shifting, Journal of Financial Economics 88, 80118. 
Janeba, E., and M. Smart (2003), Is Targeted Tax Competition Less Harmful Than Its Remedies?, International Tax and Public Finance 10, 25980.

Keen, M. (2001), Preferential Regimes Can Make Tax Competition Less Harmful, National Tax Journal 54, 757-762.

Lipponer, A. (2009), Microdatabase Direct Investment - MiDi. A Brief Guide, Deutsche Bundesbank Technical Documentation, Frankfurt.

Markusen, J.R. (2002), Multinational Firms and the Theory of International Trade, MIT Press, Cambridge.

Markusen, J.R., and K.E. Maskus (2002), Discriminating among Alternative Theories of the Multinational Enterprise, Review of International Economics 10, 694-707.

Mundlak, Y. (1978), On the Pooling of Time Series and Cross Section Data, Econometrica 46, 69-85.

Overesch, M. (2009), The Effects of Multinationals' Profit Shifting Activities on Real Investments, National Tax Journal 62, 5-23.

Overesch, M., and G. Wamser (2009), Who Cares about Corporate Taxation? Asymmetric Tax Effects on Outbound FDI, The World Economy $32,1657-1684$.

Overesch, M., and G. Wamser (2010), The Effects of Company Taxation in EU Accession Countries on German FDI, Economics of Transition 18, 429-457.

Peralta, S., X. Wauthy, and T. van Ypersele (2006), Should Countries Control International Profit Shifting?, Journal of International Economics 68, 24-37. 
Swenson, D. (2001), Transaction Type and the Effect of Taxes on the Distribution of Foreign Direct Investment in the U.S., in International Taxation and Multinational Activity, ed. by J.R. Hines, 89-108. University of Chicago Press, Chicago, IL.

Wamser, G. (2011), Foreign (In)Direct Investment and Corporate Taxation, Canadian Journal of Economics 44(4), 1497-1524.

Weichenrieder, A. (2009), Profit Shifting in the EU: Evidence from Germany, International Tax and Public Finance 16, 281-297.

Wooldridge, J.M. (2002), Econometric Analysis of Cross Section and Panel Data, MIT Press, Cambridge, MA. 


\section{Appendix}

We specify an exponential conditional mean model for an affiliate's fixed assets $y_{i t}$, where the unobserved time-invariant affiliate-specific effect $c_{i}$ enters multiplicatively, so that $E\left(y_{i t} \mid x_{i 1}, \ldots, x_{i T}, c_{i}\right)=c_{i} \exp \left(\mathbf{x}_{i t}^{\prime} \boldsymbol{\beta}^{\ell}\right)$, where $\boldsymbol{\beta}^{\ell}$ is the vector of parameters on the explanatory variables $\mathbf{x}_{i t}$. Following the Mundlak-Chamberlain-Wooldridge device, we allow $c_{i}$ to be correlated with the individual-specific averages of the regressors across all periods, $\overline{\mathbf{x}}_{i}=$ $T^{-1} \sum_{t=1}^{T} \mathbf{x}_{i t}$.

In particular, we specify $E\left(c_{i} \mid x_{i 1}, \ldots, x_{i T}\right)=\exp \left(\gamma^{\ell}+\overline{\mathbf{x}}_{i}^{\prime} \boldsymbol{\xi}^{\ell}\right)$, which implies the conditional mean

$$
E\left(y_{i t} \mid x_{i 1}, \ldots, x_{i T}\right)=\exp \left(\gamma^{\ell}+\mathbf{x}_{i t}^{\prime} \boldsymbol{\beta}^{\ell}+\overline{\mathbf{x}}_{i}^{\prime} \boldsymbol{\xi}^{\ell}\right)
$$

since, by the law of iterated expectations (e.g., see, Wooldridge, 2002, chapter $19)$.

$$
\begin{aligned}
E\left(y_{i t} \mid x_{i 1}, \ldots, x_{i T}\right) & =E\left[E\left(y_{i t} \mid x_{i 1}, \ldots, x_{i T}, c_{i}\right) \mid x_{i 1}, \ldots, x_{i T}\right] \\
& =E\left[c_{i} \exp \left(\mathbf{x}^{\prime}{ }_{i t} \boldsymbol{\beta}^{\ell}\right) \mid x_{i 1}, \ldots, x_{i T}\right] \\
& =E\left(c_{i} \mid x_{i 1}, \ldots, x_{i T}\right) \exp \left(\mathbf{x}^{\prime}{ }_{i t} \boldsymbol{\beta}^{\ell}\right) \\
& =\exp \left(\gamma^{\ell}+\mathbf{x}^{\prime}{ }_{i t} \boldsymbol{\beta}^{\ell}+\overline{\mathbf{x}}_{i}^{\prime} \boldsymbol{\xi}^{\ell}\right) .
\end{aligned}
$$

Furthermore, we specify the density $f^{\ell}\left(y_{i t} \mid \boldsymbol{\theta}^{\ell}\right)$ as a negative binomial with parameters $\mu_{i t}^{\ell}=\exp \left(\gamma^{\ell}+\mathbf{x}_{i t}^{\prime} \boldsymbol{\beta}^{\ell}+\overline{\mathbf{x}}_{i}^{\prime} \boldsymbol{\xi}^{\ell}\right)$ and $\alpha^{\ell}$, where $\boldsymbol{\theta}^{\ell}=\left(\mu_{i t}^{\ell}, \alpha^{\ell}\right), \ell=$ $\{s, n\}$.

The negative binomial distribution is obtained by assuming that the dependent variable $y_{i t}$ follows a Poisson distribution with parameter $\lambda_{i t}$, and letting $\lambda_{i t}=\mu_{i t} \nu_{i t}$, where $\nu_{i t}$ is a gamma-distributed random unobserved component with parameter $m=1 / \alpha$. The marginal distribution of $y_{i t}$ conditional on the deterministic parameters $\mu_{i t}$ and $\alpha$ is obtained by integrating $\nu_{i t}$ out, which gives

$$
\begin{aligned}
f\left(y_{i t} \mid \mu_{i t}, \alpha\right) & =\int h\left(y_{i t} \mid \mu_{i t}, \alpha\right) g\left(\nu_{i t} \mid \alpha\right) d \nu \\
& =\frac{\Gamma\left(\alpha^{-1}+y_{i t}\right)}{\Gamma\left(\alpha^{-1}\right) \Gamma\left(y_{i t}+1\right)}\left(\frac{\alpha^{-1}}{\alpha^{-1}+\mu_{i t}}\right)^{\alpha^{-1}}\left(\frac{\mu_{i t}}{\mu_{i t}+\alpha^{-1}}\right)_{i t}^{y} .
\end{aligned}
$$

Letting $\alpha$ be a parameter to be estimated obtains the conditional variance $V\left[y_{i t} \mid \mu_{i t}, \alpha\right]=\mu_{i t}\left(1+\alpha \mu_{i t}\right)$, which is quadratic in the mean allowing for overdispersion in the data. This version of the model is called negative binomial 2 (NB2). See Cameron and Trivedi (2006) for details. 


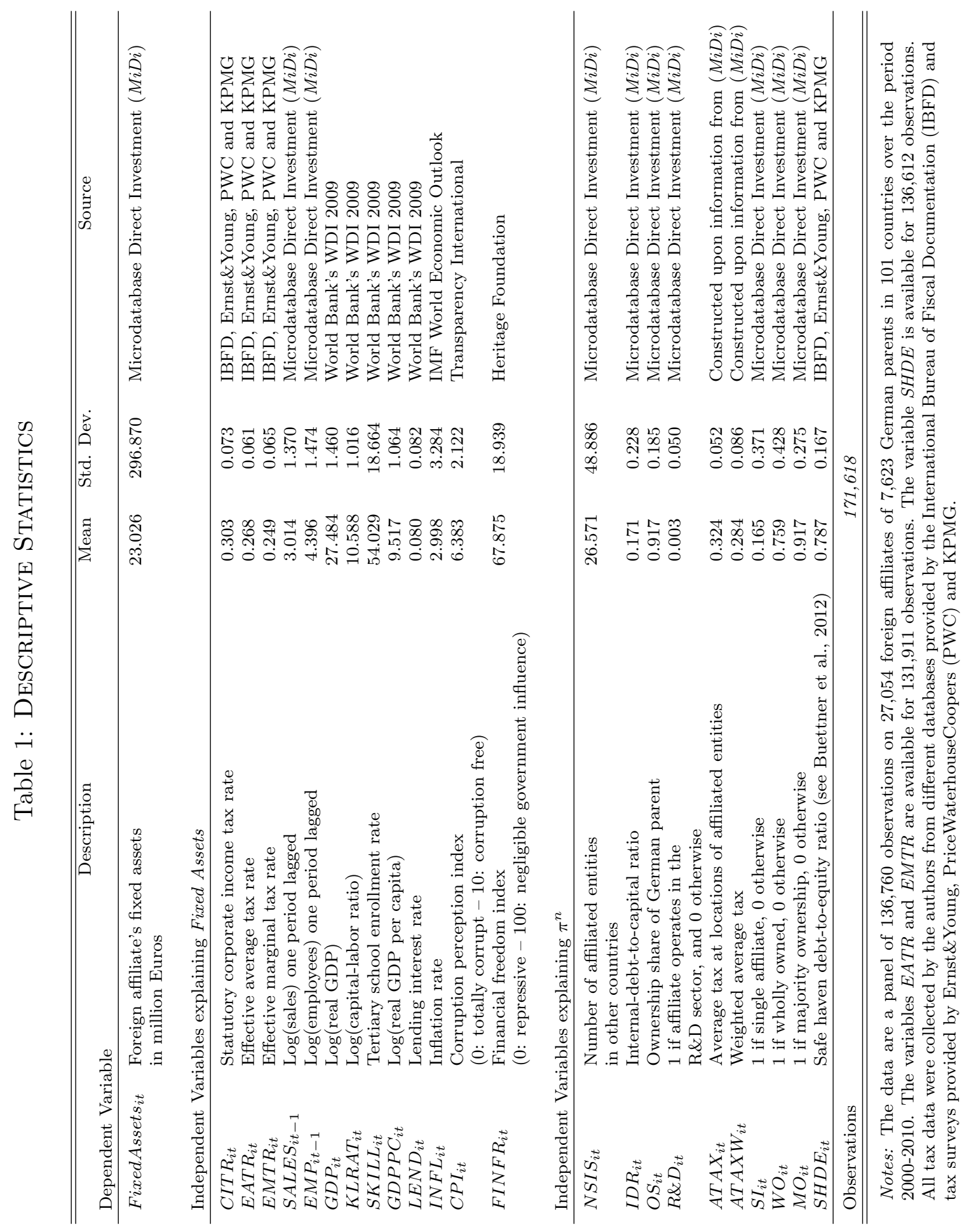


Table 2: Impact of Taxes on Non-Avoiding \& Avoiding Affiliates (Specifications I-III)

\begin{tabular}{|c|c|c|c|c|c|c|}
\hline & Specifica & \multicolumn{5}{|c|}{ Negative Binomial Mixture Model } \\
\hline & Non-avoiders & Avoiders & Non-avoiders & Avoiders & Non-avoiders & Avoiders \\
\hline$C I T R_{i t}$ & $\begin{array}{c}-.889 * * * \\
(.240)\end{array}$ & $\begin{array}{l}.671 \\
(.705)\end{array}$ & $\begin{array}{c}-.854 * * * \\
(.239)\end{array}$ & $\begin{array}{l}.753 \\
(.704)\end{array}$ & $\begin{array}{c}-.748^{* * *} \\
(.240)\end{array}$ & $\begin{array}{l}.653 \\
(.690)\end{array}$ \\
\hline$S A L E S_{i t-1}$ & $\begin{array}{c}.108^{* * *} \\
(.020)\end{array}$ & $\begin{array}{l}-.025 \\
(.036)\end{array}$ & $\begin{array}{c}.109 * * * \\
(.019)\end{array}$ & $\begin{array}{l}-.027 \\
(.035)\end{array}$ & $\begin{array}{c}.100 * * * \\
(.019)\end{array}$ & $\begin{array}{l}-.020 \\
(.035)\end{array}$ \\
\hline$E M P_{i t-1}$ & $\begin{array}{c}.428^{* * *} \\
(.023)\end{array}$ & $\begin{array}{l}.062 \\
(.043)\end{array}$ & $\begin{array}{c}.429^{* * *} \\
(.023)\end{array}$ & $\begin{array}{l}.063 \\
(.042)\end{array}$ & $\begin{array}{c}.435^{* * * *} \\
(.022)\end{array}$ & $\begin{array}{l}.065 \\
(.043)\end{array}$ \\
\hline$G D P_{i t}$ & $\begin{array}{l}.075 \\
(.088)\end{array}$ & $\begin{array}{l}-.037 \\
(.309)\end{array}$ & $\begin{array}{l}.068 \\
(.084)\end{array}$ & $\begin{array}{l}-.038 \\
(.291)\end{array}$ & $\begin{array}{l}.057 \\
(.090)\end{array}$ & $\begin{array}{l}-.091 \\
(.314)\end{array}$ \\
\hline$K L R A T_{i t}$ & $\begin{array}{c}-.091^{* *} \\
(.041)\end{array}$ & $\begin{array}{l}.137 \\
(.169)\end{array}$ & $\begin{array}{c}-.083^{* *} \\
(.041)\end{array}$ & $\begin{array}{l}.122 \\
(.171)\end{array}$ & $\begin{array}{l}-.069^{*} \\
(.042)\end{array}$ & $\begin{array}{l}.128 \\
(.164)\end{array}$ \\
\hline$S K I L L_{i t}$ & $\begin{array}{l}.002^{*} \\
(.001)\end{array}$ & $\begin{array}{l}.009^{* *} \\
(.005)\end{array}$ & $\begin{array}{l}.002^{*} \\
(.001)\end{array}$ & $\begin{array}{l}.009^{* *} \\
(.005)\end{array}$ & $\begin{array}{l}.002 \\
(.001)\end{array}$ & $\begin{array}{l}.008^{*} \\
(.004)\end{array}$ \\
\hline$G D P P C_{i t}$ & $\begin{array}{l}.147 \\
(.108)\end{array}$ & $\begin{array}{l}.843^{* *} \\
(.364)\end{array}$ & $\begin{array}{l}.142 \\
(.105)\end{array}$ & $\begin{array}{l}.808^{* *} \\
(.348)\end{array}$ & $\begin{array}{l}.167 \\
(.112)\end{array}$ & $\begin{array}{l}.739 * * \\
(.366)\end{array}$ \\
\hline$L E N D_{i t}$ & $\begin{array}{c}-.337^{*} \\
(.179)\end{array}$ & $\begin{array}{l}.199 \\
(.617)\end{array}$ & $\begin{array}{c}-.352^{* *} \\
(.178)\end{array}$ & $\begin{array}{l}.202 \\
(.624)\end{array}$ & $\begin{array}{c}-.298^{*} \\
(.173)\end{array}$ & $\begin{array}{l}.145 \\
(.611)\end{array}$ \\
\hline$I N F L_{i t}$ & $\begin{array}{c}-.015 * * * \\
(.004)\end{array}$ & $\begin{array}{l}-.007 \\
(.007)\end{array}$ & $\begin{array}{c}-.015^{* * *} \\
(.003)\end{array}$ & $\begin{array}{l}-.007 \\
(.007)\end{array}$ & $\begin{array}{c}-.016^{* * *} \\
(.003)\end{array}$ & $\begin{array}{l}-.006 \\
(.007)\end{array}$ \\
\hline$C P I_{i t}$ & $\begin{array}{c}.089^{* * *} \\
(.015)\end{array}$ & $\begin{array}{l}-.059 \\
(.052)\end{array}$ & $\begin{array}{c}.089^{* * *} \\
(.015)\end{array}$ & $\begin{array}{l}-.055 \\
(.053)\end{array}$ & $\begin{array}{c}.090^{* * * *} \\
(.014)\end{array}$ & $\begin{array}{l}-.055 \\
(.051)\end{array}$ \\
\hline$F I N F R_{i t}$ & $\begin{array}{c}.003^{* * *} \\
(.001) \\
\end{array}$ & $\begin{array}{c}.002 \\
(.003) \\
\end{array}$ & $\begin{array}{c}.003^{* * *} \\
(.001) \\
\end{array}$ & $\begin{array}{c}.002 \\
(.003) \\
\end{array}$ & $\begin{array}{c}.003^{* * *} \\
(.001) \\
\end{array}$ & $\begin{array}{c}.002 \\
(.003) \\
\end{array}$ \\
\hline \multicolumn{7}{|c|}{$\operatorname{Pr}($ Non-avoiders $)$} \\
\hline$N S I S_{i t}$ & $\begin{array}{l}-.001^{*} \\
(.001)\end{array}$ & & & & & \\
\hline$I D R_{i t}$ & & & $\begin{array}{c}-.545^{* * *} \\
(.079)\end{array}$ & & & \\
\hline$O S_{i t}$ & & & & & $\begin{array}{l}-.153 \\
(.183)\end{array}$ & \\
\hline Constant & $\begin{array}{c}1.590^{* * *} \\
(.044) \\
\end{array}$ & & $\begin{array}{c}1.446^{* * *} \\
(.053)\end{array}$ & & $\begin{array}{c}-.498^{* * * *} \\
(.121) \\
\end{array}$ & \\
\hline Predicted mean & 10.324 & 66.419 & 10.601 & 65.670 & 10.299 & 67.376 \\
\hline \% of Sample & $89.88 \%$ & $10.12 \%$ & $90.08 \%$ & $9.92 \%$ & $89.73 \%$ & $10.27 \%$ \\
\hline Observations & \multicolumn{2}{|c|}{136,760} & \multicolumn{2}{|c|}{136,760} & \multicolumn{2}{|c|}{136,760} \\
\hline
\end{tabular}

Notes: The dependent variable refers to the fixed assets of a foreign affiliate. All regressions include time dummies and affiliate-specific effects. Robust and clustered (by affiliate) standard errors are reported in parentheses. *, **, and $* * *$ indicate significance at $10 \%, 5 \%$, and $1 \%$, respectively. The percentages of the sample classified as avoiders and non-avoiders are obtained after estimation using the calculated posterior probability of being one or the other. 


\section{Table 3: Impact of Taxes on Non-Avoiding \& Avoiding Affiliates (Specifications $I V-V I$ )}

\begin{tabular}{|c|c|c|c|c|c|c|}
\hline & \multicolumn{3}{|c|}{ Negative Binomial Mixture Model } & $\begin{array}{l}\text { Mixture Mc } \\
\text { on V }\end{array}$ & Specificat & n VI \\
\hline & Non-avoiders & Avoiders & Non-avoiders & Avoiders & Non-avoiders & Avoiders \\
\hline$C I T R_{i t}$ & $\begin{array}{c}-.849^{* * *} \\
(.238)\end{array}$ & $\begin{array}{l}.782 \\
(.707)\end{array}$ & $\begin{array}{c}-.931 * * * \\
(.239)\end{array}$ & $\begin{array}{l}.607 \\
(.703)\end{array}$ & $\begin{array}{c}-.843^{* * *} \\
(.238)\end{array}$ & $\begin{array}{c}.841 \\
(.707)\end{array}$ \\
\hline$S A L E S_{i t-1}$ & $\begin{array}{c}.108^{* * *} \\
(.019)\end{array}$ & $\begin{array}{l}-.026 \\
(.035)\end{array}$ & $\begin{array}{c}.110^{* * *} \\
(.020)\end{array}$ & $\begin{array}{l}-.023 \\
(.036)\end{array}$ & $\begin{array}{c}.108^{* * * *} \\
(.020)\end{array}$ & $\begin{array}{l}-.024 \\
(.036)\end{array}$ \\
\hline$E M P_{i t-1}$ & $\begin{array}{c}.428^{* * *} \\
(.023)\end{array}$ & $\begin{array}{l}.063 \\
(.043)\end{array}$ & $\begin{array}{c}.423^{* * *} \\
(.023)\end{array}$ & $\begin{array}{l}.065 \\
(.043)\end{array}$ & $\begin{array}{c}.424^{* * * *} \\
(.023)\end{array}$ & $\begin{array}{l}.064 \\
(.043)\end{array}$ \\
\hline$G D P_{i t}$ & $\begin{array}{l}.074 \\
(.086)\end{array}$ & $\begin{array}{l}-.050 \\
(.302)\end{array}$ & $\begin{array}{l}.094 \\
(.084)\end{array}$ & $\begin{array}{l}.016 \\
(.290)\end{array}$ & $\begin{array}{l}.077 \\
(.084)\end{array}$ & $\begin{array}{l}-.040 \\
(.298)\end{array}$ \\
\hline$K L R A T_{i t}$ & $\begin{array}{c}-.084^{* *} \\
(.041)\end{array}$ & $\begin{array}{l}.127 \\
(.172)\end{array}$ & $\begin{array}{c}-.094^{* *} \\
(.041)\end{array}$ & $\begin{array}{l}.140 \\
(.173)\end{array}$ & $\begin{array}{c}-.087^{* *} \\
(.041)\end{array}$ & $\begin{array}{l}.142 \\
(.174)\end{array}$ \\
\hline$S K I L L_{i t}$ & $\begin{array}{l}.002^{*} \\
(.001)\end{array}$ & $\begin{array}{l}.009^{* *} \\
(.005)\end{array}$ & $\begin{array}{l}.002^{* *} \\
(.001)\end{array}$ & $\begin{array}{l}.010^{* *} \\
(.005)\end{array}$ & $\begin{array}{l}.002^{*} \\
(.001)\end{array}$ & $\begin{array}{l}.009^{*} \\
(.005)\end{array}$ \\
\hline$G D P P C_{i t}$ & $\begin{array}{l}.145 \\
(.107)\end{array}$ & $\begin{array}{l}.818^{* *} \\
(.359)\end{array}$ & $\begin{array}{l}.145 \\
(.105)\end{array}$ & $\begin{array}{l}.836^{* *} \\
(.346)\end{array}$ & $\begin{array}{l}.145 \\
(.105)\end{array}$ & $\begin{array}{l}.805^{* *} \\
(.354)\end{array}$ \\
\hline$L E N D_{i t}$ & $\begin{array}{c}-.337^{*} \\
(.178)\end{array}$ & $\begin{array}{l}.215 \\
(.627)\end{array}$ & $\begin{array}{l}-.338^{*} \\
(.175)\end{array}$ & $\begin{array}{l}.199 \\
(.628)\end{array}$ & $\begin{array}{c}-.346^{*} \\
(.177)\end{array}$ & $\begin{array}{l}.218 \\
(.631)\end{array}$ \\
\hline$I N F L_{i t}$ & $\begin{array}{c}-.015^{* * *} \\
(.003)\end{array}$ & $\begin{array}{l}-.007 \\
(.007)\end{array}$ & $\begin{array}{c}-.015^{* * *} \\
(.003)\end{array}$ & $\begin{array}{l}-.007 \\
(.007)\end{array}$ & $\begin{array}{c}-.015^{* * *} \\
(.003)\end{array}$ & $\begin{array}{l}-.007 \\
(.007)\end{array}$ \\
\hline$C P I_{i t}$ & $\begin{array}{c}.088^{* * * *} \\
(.015)\end{array}$ & $\begin{array}{l}-.056 \\
(.053)\end{array}$ & $\begin{array}{c}.085^{* * *} \\
(.015)\end{array}$ & $\begin{array}{l}-.065 \\
(.053)\end{array}$ & $\begin{array}{c}.086^{* * *} \\
(.015)\end{array}$ & $\begin{array}{l}-.055 \\
(.053)\end{array}$ \\
\hline$F I N F R_{i t}$ & $\begin{array}{c}.003^{* * *} \\
(.001) \\
\end{array}$ & $\begin{array}{c}.002 \\
(.003) \\
\end{array}$ & $\begin{array}{c}.003^{* * *} \\
(.001)\end{array}$ & $\begin{array}{c}.002 \\
(.003) \\
\end{array}$ & $\begin{array}{c}.003^{* * * *} \\
(.001)\end{array}$ & $\begin{array}{c}.002 \\
(.003) \\
\end{array}$ \\
\hline \multicolumn{7}{|l|}{$\operatorname{Pr}($ Non-avoiders $)$} \\
\hline$R \& D_{i t}$ & $\begin{array}{l}-.033 \\
(.377)\end{array}$ & & & & & \\
\hline$A T A X_{i t}$ & & & $\begin{array}{l}.676 \\
(.511)\end{array}$ & & & \\
\hline$A T A X W_{i t}$ & & & & & $\begin{array}{c}1.202^{* * * *} \\
(.249)\end{array}$ & \\
\hline Constant & $\begin{array}{c}1.515^{* * *} \\
(.042) \\
\end{array}$ & & $\begin{array}{r}.231 \\
(.243) \\
\end{array}$ & & $\begin{array}{c}1.016^{* * *} \\
(.121) \\
\end{array}$ & \\
\hline Predicted mean & 10.615 & 65.517 & 10.436 & 66.172 & 10.482 & 66.871 \\
\hline$\%$ of sample & $90.13 \%$ & $9.87 \%$ & $90.11 \%$ & $9.89 \%$ & $90.17 \%$ & $9.83 \%$ \\
\hline Observations & \multicolumn{2}{|c|}{136,760} & \multicolumn{2}{|c|}{136,760} & \multicolumn{2}{|c|}{136,760} \\
\hline
\end{tabular}

Notes: The dependent variable refers to the fixed assets of a foreign affiliate. All regressions include time dummies and affiliate-specific effects. Robust and clustered (by affiliate) standard errors are reported in parentheses. *,**, and $* * *$ indicate significance at $10 \%, 5 \%$, and $1 \%$, respectively. The percentages of the sample classified as avoiders and non-avoiders are obtained after estimation using the calculated posterior probability of being one or the other. 


\section{Table 4: Impact of Taxes on Non-Avoiding \& Avoiding Affiliates (Specifications VII-IX)}

\begin{tabular}{|c|c|c|c|c|c|c|}
\hline & Specificati & n VII & $\begin{array}{r}\text { ative Binomial } \\
\text { Specificati }\end{array}$ & $\begin{array}{l}\text { lixture M } \\
\text { VIII }\end{array}$ & Specificat & n IX \\
\hline & Non-avoiders & Avoiders & Non-avoiders & Avoiders & Non-avoiders & Avoiders \\
\hline$C I T R_{i t}$ & $\begin{array}{c}-.834^{* * *} \\
(.238)\end{array}$ & $\begin{array}{l}.892 \\
(.705)\end{array}$ & $\begin{array}{c}-.787^{* * *} \\
(.241)\end{array}$ & $\begin{array}{c}.684 \\
(.693)\end{array}$ & $\begin{array}{c}-.754^{* * *} \\
(.239)\end{array}$ & $\begin{array}{l}.745 \\
(.693)\end{array}$ \\
\hline$S A L E S_{i t-1}$ & $\begin{array}{c}.107^{* * * *} \\
(.019)\end{array}$ & $\begin{array}{l}-.029 \\
(.035)\end{array}$ & $\begin{array}{c}.104^{* * * *} \\
(.019)\end{array}$ & $\begin{array}{l}-.021 \\
(.035)\end{array}$ & $\begin{array}{c}.099 * * * \\
(.019)\end{array}$ & $\begin{array}{l}-.021 \\
(.035)\end{array}$ \\
\hline$E M P_{i t-1}$ & $\begin{array}{c}.429 * * * \\
(.022)\end{array}$ & $\begin{array}{l}.061 \\
(.042)\end{array}$ & $\begin{array}{c}.431^{* * *} \\
(.023)\end{array}$ & $\begin{array}{l}.063 \\
(.042)\end{array}$ & $\begin{array}{c}.433^{* * *} \\
(.022)\end{array}$ & $\begin{array}{l}.064 \\
(.042)\end{array}$ \\
\hline$G D P_{i t}$ & $\begin{array}{l}.075 \\
(.095)\end{array}$ & $\begin{array}{l}-.092 \\
(.358)\end{array}$ & $\begin{array}{l}.070 \\
(.090)\end{array}$ & $\begin{array}{l}-.085 \\
(.325)\end{array}$ & $\begin{array}{l}.047 \\
(.090)\end{array}$ & $\begin{array}{l}-.092 \\
(.314)\end{array}$ \\
\hline$K L R A T_{i t}$ & $\begin{array}{c}-.084^{* *} \\
(.041)\end{array}$ & $\begin{array}{l}.120 \\
(.174)\end{array}$ & $\begin{array}{l}-.071^{*} \\
(.042)\end{array}$ & $\begin{array}{l}.123 \\
(.166)\end{array}$ & $\begin{array}{l}-.077^{*} \\
(.041)\end{array}$ & $\begin{array}{l}.139 \\
(.166)\end{array}$ \\
\hline$S K I L L_{i t}$ & $\begin{array}{l}.002^{*} \\
(.001)\end{array}$ & $\begin{array}{l}.009^{*} \\
(.005)\end{array}$ & $\begin{array}{l}.002 \\
(.001)\end{array}$ & $\begin{array}{l}.009 * * \\
(.004)\end{array}$ & $\begin{array}{l}.002^{*} \\
(.001)\end{array}$ & $\begin{array}{l}.008^{*} \\
(.004)\end{array}$ \\
\hline$G D P P C_{i t}$ & $\begin{array}{l}.131 \\
(.116)\end{array}$ & $\begin{array}{l}.831^{* *} \\
(.411)\end{array}$ & $\begin{array}{l}.155 \\
(.111)\end{array}$ & $\begin{array}{l}.757^{* *} \\
(.377)\end{array}$ & $\begin{array}{l}.153 \\
(.112)\end{array}$ & $\begin{array}{l}.774^{* *} \\
(.366)\end{array}$ \\
\hline$L E N D_{i t}$ & $\begin{array}{c}-.363^{* *} \\
(.179)\end{array}$ & $\begin{array}{l}.254 \\
(.632)\end{array}$ & $\begin{array}{l}-.319^{*} \\
(.175)\end{array}$ & $\begin{array}{l}.171 \\
(.616)\end{array}$ & $\begin{array}{c}-.312^{*} \\
(.176)\end{array}$ & $\begin{array}{l}.141 \\
(.611)\end{array}$ \\
\hline$I N F L_{i t}$ & $\begin{array}{c}-.014^{* * *} \\
(.004)\end{array}$ & $\begin{array}{l}-.006 \\
(.007)\end{array}$ & $\begin{array}{c}-.015^{* * *} \\
(.004)\end{array}$ & $\begin{array}{l}-.006 \\
(.007)\end{array}$ & $\begin{array}{c}-.015^{* * *} \\
(.003)\end{array}$ & $\begin{array}{l}-.006 \\
(.007)\end{array}$ \\
\hline$C P I_{i t}$ & $\begin{array}{c}.090^{* * *} \\
(.015)\end{array}$ & $\begin{array}{l}-.051 \\
(.053)\end{array}$ & $\begin{array}{c}.090^{* * *} \\
(.015)\end{array}$ & $\begin{array}{l}-.057 \\
(.052)\end{array}$ & $\begin{array}{c}.092^{* * *} \\
(.015)\end{array}$ & $\begin{array}{l}-.055 \\
(.052)\end{array}$ \\
\hline$F I N F R_{i t}$ & $\begin{array}{c}.003^{* * *} \\
(.001)\end{array}$ & $\begin{array}{l}.002 \\
(.003)\end{array}$ & $\begin{array}{c}.003^{* * *} \\
(.001)\end{array}$ & $\begin{array}{l}.002 \\
(.003)\end{array}$ & $\begin{array}{c}.003^{* * *} \\
(.001)\end{array}$ & $\begin{array}{l}.002 \\
(.003)\end{array}$ \\
\hline $\begin{array}{l}\operatorname{Pr}(\text { Non-avoider } \\
S I_{i t}\end{array}$ & $\begin{array}{l}.053 \\
(.066)\end{array}$ & & & & & \\
\hline$W O_{i t}$ & & & $\begin{array}{l}-.043 \\
(.061)\end{array}$ & & & \\
\hline$M O_{i t}$ & & & & & $\begin{array}{c}-.270^{* *} \\
(.120)\end{array}$ & \\
\hline Constant & $\begin{array}{c}1.649^{* * *} \\
(.046) \\
\end{array}$ & & $\begin{array}{c}.867^{* * *} \\
(.059) \\
\end{array}$ & & $\begin{array}{c}.300^{* * *} \\
(.083) \\
\end{array}$ & \\
\hline Predicted mean & 10.906 & $\begin{array}{l}64.603 \\
9.87 \%\end{array}$ & 10.512 & 66.102 & 10.385 & 66.930 \\
\hline $\begin{array}{l}\% \text { of sample } \\
\text { Observations }\end{array}$ & $\begin{array}{r}90.13 \% \\
136,7\end{array}$ & $9.87 \%$ & $\begin{array}{r}89.86 \% \\
136,7\end{array}$ & $10.14 \%$ & $\begin{array}{r}89.77 \% \\
136,7\end{array}$ & \\
\hline
\end{tabular}

Notes: The dependent variable refers to the fixed assets of a foreign affiliate. All regressions include time dummies and affiliate-specific effects. Robust and clustered (by affiliate) standard errors are reported in parentheses. *, **, and $* * *$ indicate significance at $10 \%, 5 \%$, and $1 \%$, respectively. The percentages of the sample classified as avoiders and non-avoiders are obtained after estimation using the calculated posterior probability of being one or the other. 
Table 5: Impact of Taxes on Non-Avoiding \& Avoiding Affiliates (Specifications $X-X I$ )

\begin{tabular}{|c|c|c|c|c|}
\hline & \multicolumn{4}{|c|}{ Negative Binomial Mixture Model } \\
\hline & \multicolumn{2}{|c|}{ Specification X } & \multicolumn{2}{|c|}{ Specification XI } \\
\hline & Non-avoiders & Avoiders & Non-avoiders & Avoiders \\
\hline \multirow[t]{2}{*}{$C I T R_{i t}$} & $-.897 * * *$ & .561 & $-.808^{* * *}$ & .232 \\
\hline & $(.241)$ & $(.717)$ & $(.246)$ & $(.694)$ \\
\hline \multirow[t]{2}{*}{$S A L E S_{i t-1}$} & $.108^{* * *}$ & -.022 & $.102^{* * *}$ & -.014 \\
\hline & $(.019)$ & $(.035)$ & $(.021)$ & $(.036)$ \\
\hline \multirow[t]{2}{*}{$E M P_{i t-1}$} & $.430 * * *$ & .060 & $.427^{* * *}$ & .064 \\
\hline & $(.023)$ & $(.043)$ & $(.024)$ & $(.044)$ \\
\hline \multirow[t]{2}{*}{$G D P_{i t}$} & .078 & -.016 & .080 & -.007 \\
\hline & $(.085)$ & $(.289)$ & $(.090)$ & $(.317)$ \\
\hline \multirow[t]{2}{*}{$K L R A T_{i t}$} & $-.079^{*}$ & .138 & $-.078^{*}$ & .152 \\
\hline & $(.041)$ & $(.169)$ & $(.042)$ & $(.160)$ \\
\hline \multirow[t]{2}{*}{$S K I L L_{i t}$} & $.002 *$ & $.010^{* *}$ & $.002 *$ & $.009 * *$ \\
\hline & $(.001)$ & $(.005)$ & $(.001)$ & $(.004)$ \\
\hline \multirow[t]{2}{*}{$G D P P C_{i t}$} & .148 & $.821^{* *}$ & .160 & $.757^{* *}$ \\
\hline & $(.107)$ & $(.344)$ & $(.111)$ & $(.365)$ \\
\hline \multirow[t]{2}{*}{$L E N D_{i t}$} & $-.315^{*}$ & .182 & $-.314^{*}$ & .099 \\
\hline & $(.177)$ & $(.618)$ & $(.177)$ & $(.593)$ \\
\hline \multirow[t]{2}{*}{$I N F L_{i t}$} & $-.015^{* * *}$ & -.006 & $-.015 * * *$ & -.005 \\
\hline & $(.003)$ & $(.007)$ & $(.004)$ & $(.007)$ \\
\hline \multirow[t]{2}{*}{$C P I_{i t}$} & $.090^{* * *}$ & -.062 & $.092^{* * *}$ & -.059 \\
\hline & $(.015)$ & $(.052)$ & $(.015)$ & $(.051)$ \\
\hline \multirow{2}{*}{$F I N F R_{i t}$} & $.003^{* * *}$ & .001 & $.003^{* * *}$ & .002 \\
\hline & $(.001)$ & $(.003)$ & $(.001)$ & $(.003)$ \\
\hline \multicolumn{5}{|l|}{$\operatorname{Pr}($ Non-avoiders $)$} \\
\hline$S H D E_{i t}$ & $\begin{array}{c}-.707^{* * *} \\
(.155)\end{array}$ & & & \\
\hline$N S I S_{i t}$ & & & $\begin{array}{c}-.001^{* *} \\
(.001)\end{array}$ & \\
\hline \multirow[t]{2}{*}{$I D R_{i t}$} & & & $-.554 * * *$ & \\
\hline & & & $(.083)$ & \\
\hline$O S_{i t}$ & & & -.127 & \\
\hline \multirow{2}{*}{$R \& D_{i t}$} & & & $\begin{array}{l}(.185) \\
-.054\end{array}$ & \\
\hline & & & $(.482)$ & \\
\hline \multirow[t]{2}{*}{$S I_{i t}$} & & & $-.166^{* *}$ & \\
\hline & & & $(.079)$ & \\
\hline \multirow[t]{2}{*}{$A T A X W_{i t}$} & & & $1.311^{* * *}$ & \\
\hline & & & $(.278)$ & \\
\hline \multirow[t]{2}{*}{$S H D E_{i t}$} & & & $-.578^{* * *}$ & \\
\hline & & & $\begin{array}{l}(.166) \\
700 * * *\end{array}$ & \\
\hline Constant & $\begin{array}{c}2.074^{4} \\
(.132)\end{array}$ & & $\begin{array}{c}-.799^{21 *} \\
(.221)\end{array}$ & \\
\hline \multirow{3}{*}{$\begin{array}{l}\text { Predicted mean } \\
\% \text { of sample } \\
\text { Observations }\end{array}$} & 10.756 & 65.373 & 9.635 & 67.798 \\
\hline & $90.16 \%$ & $9.84 \%$ & $88.92 \%$ & $11.08 \%$ \\
\hline & 136,6 & & 136,6 & \\
\hline
\end{tabular}

Notes: The dependent variable refers to the fixed assets of a foreign affiliate. All regressions include time dummies and affiliate-specific effects. Robust and clustered (by affiliate) standard errors are reported in parentheses. *, **, and $* * *$ indicate significance at $10 \%, 5 \%$, and $1 \%$, respectively. The percentages of the sample classified as avoiders and non-avoiders are obtained after estimation using the calculated posterior probability of being one or the other. 


\section{Table 6: Component Characteristics}

\begin{tabular}{|c|c|c|}
\hline & Non-avoiders & Avoiders \\
\hline Observations & 121,453 & 15,159 \\
\hline$\%$ of sample & 88.92 & 11.08 \\
\hline Affiliates & 24,494 & 4,824 \\
\hline German MNEs & 7,047 & 2,257 \\
\hline$\%$ of total fixed assets & 42.36 & 57.64 \\
\hline \multicolumn{3}{|l|}{ Component means } \\
\hline FixedAssets $_{i t}$ & 10.978 & 119.672 \\
\hline$S A L E S_{i t}$ & 77.739 & 173.551 \\
\hline$E M P_{i t}$ & 263.948 & 461.741 \\
\hline$N S I S_{i t}$ & 25.359 & 36.012 \\
\hline$I D R_{i t}$ & 0.171 & 0.173 \\
\hline$O S_{i t}$ & 0.928 & 0.830 \\
\hline$R \& D_{i t}$ & 0.002 & 0.006 \\
\hline$A T A X_{i t}$ & 0.324 & 0.318 \\
\hline$A T A X W_{i t}$ & 0.285 & 0.271 \\
\hline$S I_{i t}$ & 0.155 & 0.243 \\
\hline$W O_{i t}$ & 0.778 & 0.614 \\
\hline$M O_{i t}$ & 0.932 & 0.799 \\
\hline$S H D E_{i t}$ & 0.787 & 0.805 \\
\hline$C I T R_{i t}$ & 0.306 & 0.299 \\
\hline$E A T R_{i t}$ & 0.271 & 0.266 \\
\hline$E M T R_{i t}$ & 0.251 & 0.247 \\
\hline$G D P_{i t}$ & 27.484 & 27.360 \\
\hline$K L R A T_{i t}$ & 10.587 & 10.540 \\
\hline$S K I L L_{i t}$ & 53.396 & 52.932 \\
\hline$G D P P C_{i t}$ & 9.505 & 9.461 \\
\hline$L E N D_{i t}$ & 0.083 & 0.079 \\
\hline$I N F L_{i t}$ & 3.045 & 3.204 \\
\hline$C P I_{i t}$ & 6.371 & 6.332 \\
\hline$F I N F R_{i t}$ & 67.641 & 67.246 \\
\hline
\end{tabular}

Notes: The classification of observations into non-avoiders and avoiders according to the posterior probability of being one or the other is based on specification XI of Table 5 The percentages of total fixed assets for the two types of firms refers to the total of fixed assets of all German affiliates abroad held by the two types over all years in the sample (2000-2010). 


\section{Table 7: Robustness Results - Specifications XII-XIV}

\begin{tabular}{|c|c|c|c|c|c|c|}
\hline & \multicolumn{6}{|c|}{ Negative Binomial Mixture Model } \\
\hline & \multicolumn{2}{|c|}{ Specification XII } & \multicolumn{2}{|c|}{ Specification XIII } & \multicolumn{2}{|c|}{ Specification XIV } \\
\hline & Non-avoiders & Avoiders & Non-avoiders & Avoiders & Non-avoiders & Avoiders \\
\hline$E A T R_{i t}$ & $\begin{array}{c}-1.078^{* * *} \\
(.214)\end{array}$ & $\begin{array}{c}0.564 \\
(0.603)\end{array}$ & & & & \\
\hline$E M T R_{i t}$ & & & $\begin{array}{c}-.738^{* * *} \\
(.166)\end{array}$ & $\begin{array}{l}0.333 \\
(.485)\end{array}$ & & \\
\hline$C I T R_{i t}$ & & & & & $\begin{array}{c}-1.937 * * * \\
(0.274)\end{array}$ & $\begin{array}{l}-0.930 \\
(0.886)\end{array}$ \\
\hline$S A L E S_{i t}$ & $\begin{array}{c}0.073^{* *} \\
(.033)\end{array}$ & $\begin{array}{c}0.128^{* * *} \\
(0.044)\end{array}$ & $\begin{array}{l}.073^{* *} \\
(.033)\end{array}$ & $\begin{array}{c}0.128^{* * *} \\
(.044)\end{array}$ & & \\
\hline$E M P_{i t}$ & $\begin{array}{c}0.298^{* * *} \\
(.023)\end{array}$ & $\begin{array}{c}-0.104^{* *} \\
(0.049)\end{array}$ & $\begin{array}{c}.299^{* * *} * \\
(.023)\end{array}$ & $\begin{array}{c}-0.104^{* *} \\
(.049)\end{array}$ & & \\
\hline$G D P_{i t}$ & $\begin{array}{c}-0.086 \\
(.125)\end{array}$ & $\begin{array}{c}-2.113 \\
(1.580)\end{array}$ & $\begin{array}{c}-.101 \\
(.129)\end{array}$ & $\begin{array}{c}-2.161 \\
(1.649)\end{array}$ & $\begin{array}{c}0.424^{* * *} \\
(0.136)\end{array}$ & $\begin{array}{c}0.040 \\
(0.465)\end{array}$ \\
\hline$K L R A T_{i t}$ & $\begin{array}{l}0.059 \\
(.046)\end{array}$ & $\begin{array}{l}-0.103 \\
(0.086)\end{array}$ & $\begin{array}{l}.054 \\
(.046)\end{array}$ & $\begin{array}{c}-0.094 \\
(.087)\end{array}$ & $\begin{array}{c}0.016 \\
(0.040)\end{array}$ & $\begin{array}{c}0.084 \\
(0.134)\end{array}$ \\
\hline$S K I L L_{i t}$ & $\begin{array}{c}0.002^{*} \\
(.001)\end{array}$ & $\begin{array}{l}-0.001 \\
(0.003)\end{array}$ & $\begin{array}{l}.002^{*} \\
(.001)\end{array}$ & $\begin{array}{l}-0.001 \\
(.003)\end{array}$ & $\begin{array}{c}0.001 \\
(0.001)\end{array}$ & $\begin{array}{l}-0.001 \\
(0.005)\end{array}$ \\
\hline$G D P P C_{i t}$ & $\begin{array}{c}0.497^{* * *} \\
(.175)\end{array}$ & $\begin{array}{l}2.543^{*} \\
(1.560)\end{array}$ & $\begin{array}{c}.542^{* * *} \\
(.180)\end{array}$ & $\begin{array}{c}2.532 \\
(1.629)\end{array}$ & $\begin{array}{c}0.796^{* * *} \\
(0.163)\end{array}$ & $\begin{array}{l}1.31^{* * *} \\
(0.450)\end{array}$ \\
\hline$L E N D_{i t}$ & $\begin{array}{c}0.724^{* * *} \\
(.194)\end{array}$ & $\begin{array}{c}1.342^{* *} \\
(0.578)\end{array}$ & $\begin{array}{c}.695^{* * *} \\
(.194)\end{array}$ & $\begin{array}{c}1.362^{* *} \\
(.580)\end{array}$ & $\begin{array}{c}-0.629^{* * *} \\
(0.184)\end{array}$ & $\begin{array}{l}-0.690 \\
(0.458)\end{array}$ \\
\hline$I N F L_{i t}$ & $\begin{array}{c}-0.026^{* * *} \\
(.003)\end{array}$ & $\begin{array}{c}-0.027^{* * * *} \\
(0.008)\end{array}$ & $\begin{array}{c}-.026^{* * *} \\
(.003)\end{array}$ & $\begin{array}{c}-0.027^{* * *} \\
(.009)\end{array}$ & $\begin{array}{c}-0.003^{*} \\
(0.002)\end{array}$ & $\begin{array}{l}-0.005 \\
(0.005)\end{array}$ \\
\hline$C P I_{i t}$ & $\begin{array}{c}0.096^{* * *} \\
(.012)\end{array}$ & $\begin{array}{c}0.058 \\
(0.041)\end{array}$ & $\begin{array}{c}.100^{* * *} \\
(.012)\end{array}$ & $\begin{array}{l}0.056 \\
(.041)\end{array}$ & $\begin{array}{c}0.040^{* *} \\
(0.017)\end{array}$ & $\begin{array}{l}-0.020 \\
(0.050)\end{array}$ \\
\hline$F I N F R_{i t}$ & $\begin{array}{c}-0.0003 \\
(.001) \\
\end{array}$ & $\begin{array}{l}-0.001 \\
(0.002) \\
\end{array}$ & $\begin{array}{r}-.0002 \\
(.001) \\
\end{array}$ & $\begin{array}{c}-0.002 \\
(.002) \\
\end{array}$ & $\begin{array}{c}0.001 \\
(0.001) \\
\end{array}$ & $\begin{array}{c}0.002 \\
(0.002) \\
\end{array}$ \\
\hline \multicolumn{7}{|l|}{$\operatorname{Pr}($ Non-avoiders } \\
\hline$N S I S_{i t}$ & $\begin{array}{c}-0.001^{* *} \\
(0.001)\end{array}$ & & $\begin{array}{c}-0.001^{* *} \\
(0.001)\end{array}$ & & $\begin{array}{c}-0.004^{* * *} \\
(0.001)\end{array}$ & \\
\hline$I D R_{i t}$ & $\begin{array}{c}-0.258^{* * * *} \\
(0.074)\end{array}$ & & $\begin{array}{c}-0.259^{* * *} \\
(0.074)\end{array}$ & & $\begin{array}{c}-0.248^{* * *} \\
(0.064)\end{array}$ & \\
\hline$R \& D_{i t}$ & $\begin{array}{c}0.119 \\
(0.159)\end{array}$ & & $\begin{array}{c}0.123 \\
(0.159)\end{array}$ & & $\begin{array}{c}-0.409 \\
(0.464)\end{array}$ & \\
\hline$S A_{i t}$ & $\begin{array}{l}-0.120 \\
(0.498)\end{array}$ & & $\begin{array}{l}-0.098 \\
(0.497)\end{array}$ & & $\begin{array}{c}-0.328^{* * *} \\
(0.061)\end{array}$ & \\
\hline$A T A X W_{i t}$ & $\begin{array}{c}-0.171^{* * *} \\
(0.066)\end{array}$ & & $\begin{array}{c}-0.172^{* * *} \\
(0.066)\end{array}$ & & $\begin{array}{c}2.703^{* * *} \\
(0.233)\end{array}$ & \\
\hline$O S_{i t}$ & $\begin{array}{c}1.453^{* * *} \\
(0.220)\end{array}$ & & $\begin{array}{c}1.451^{* * *} \\
(0.221)\end{array}$ & & $\begin{array}{c}-0.031 \\
(0.129)\end{array}$ & \\
\hline$S H D E_{i t}$ & $\begin{array}{c}-0.916^{* * *} \\
(0.201)\end{array}$ & & $\begin{array}{c}-0.903^{* * *} \\
(0.201)\end{array}$ & & $0.479 * *$ & \\
\hline Constant & $\begin{array}{c}-0.458^{*} \\
(0.248)\end{array}$ & & $\begin{array}{c}-0.470^{*} \\
(0.248)\end{array}$ & & $\begin{array}{c}-2.228^{* * *} \\
(0.239)\end{array}$ & \\
\hline Predicted mean & 10.088 & 66.235 & 9.590 & 65.764 & 3.486 & 95.992 \\
\hline $\begin{array}{l}\% \text { of sample } \\
\text { Observations }\end{array}$ & 102,895 & $5^{10.42}$ & \multicolumn{2}{|c|}{102,895} & \multicolumn{2}{|c|}{171,618} \\
\hline
\end{tabular}

Notes: The dependent variable refers to the fixed assets of a foreign affiliate. All regressions include time dummies and affiliate-specific effects. Robust and clustered (by affiliate) standard errors are reported in parentheses. *, **, and $* * *$ indicate significance at $10 \%, 5 \%$, and $1 \%$, respectively. The percentages of the sample classified as shifters and non-shifters are obtained after estimation using the calculated posterior probability of being one or the other. 


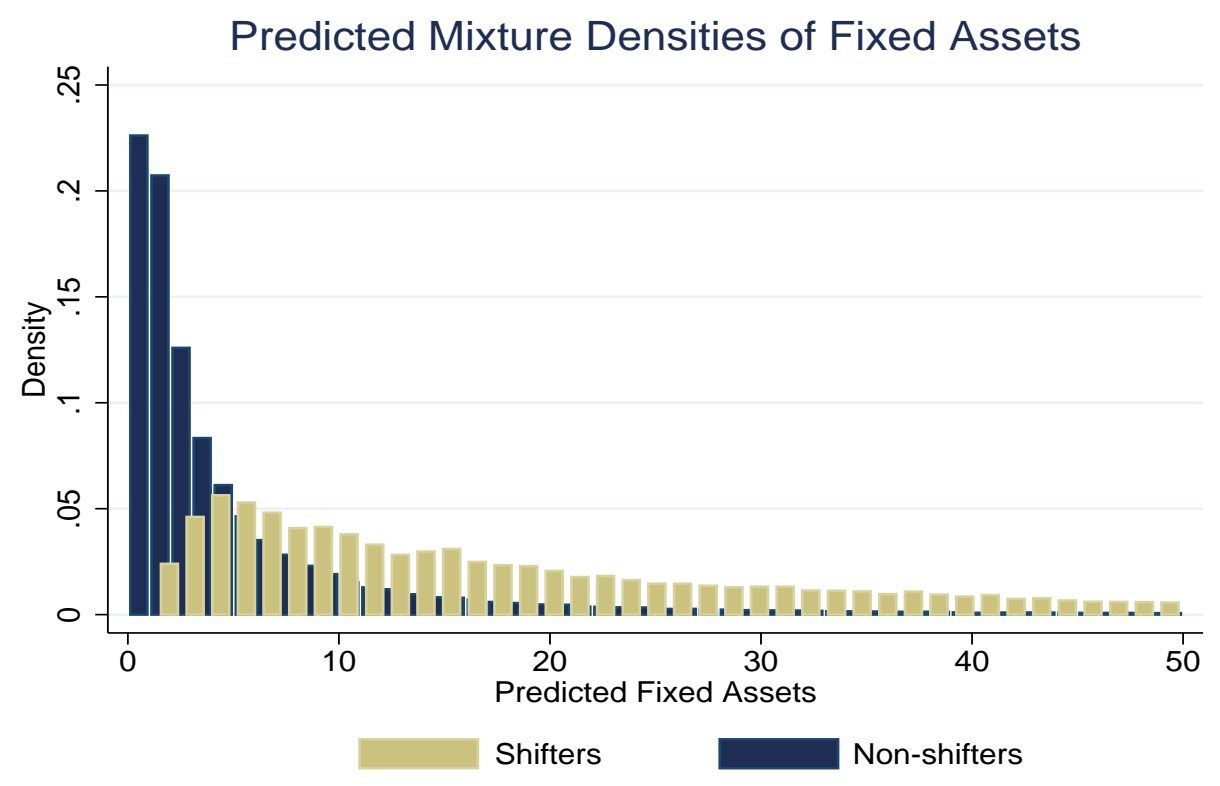

Figure 1: Predicted mixture densities of fixed assets 

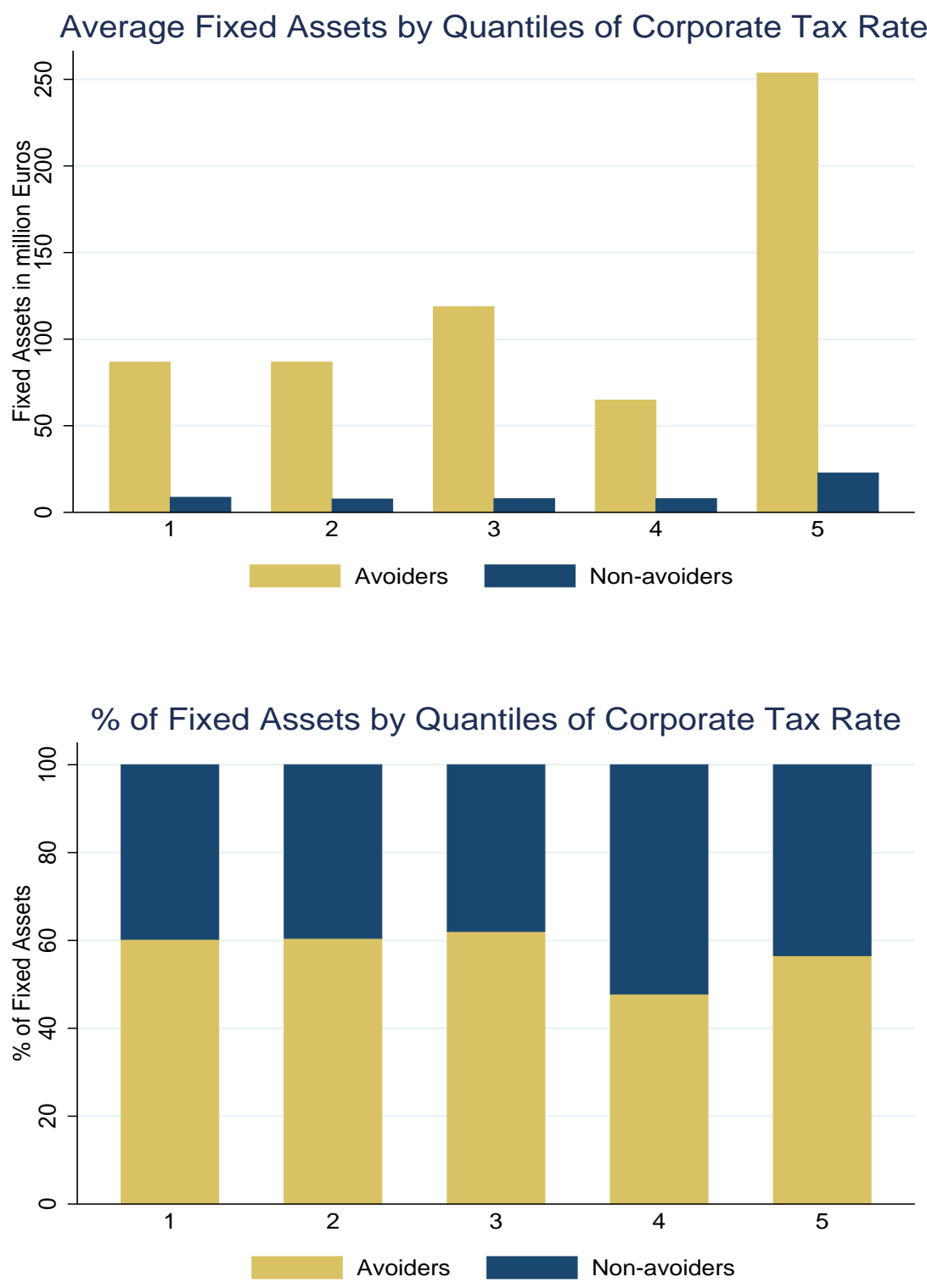

Figure 2: Fixed assets by quintiles of corporate tax rate 

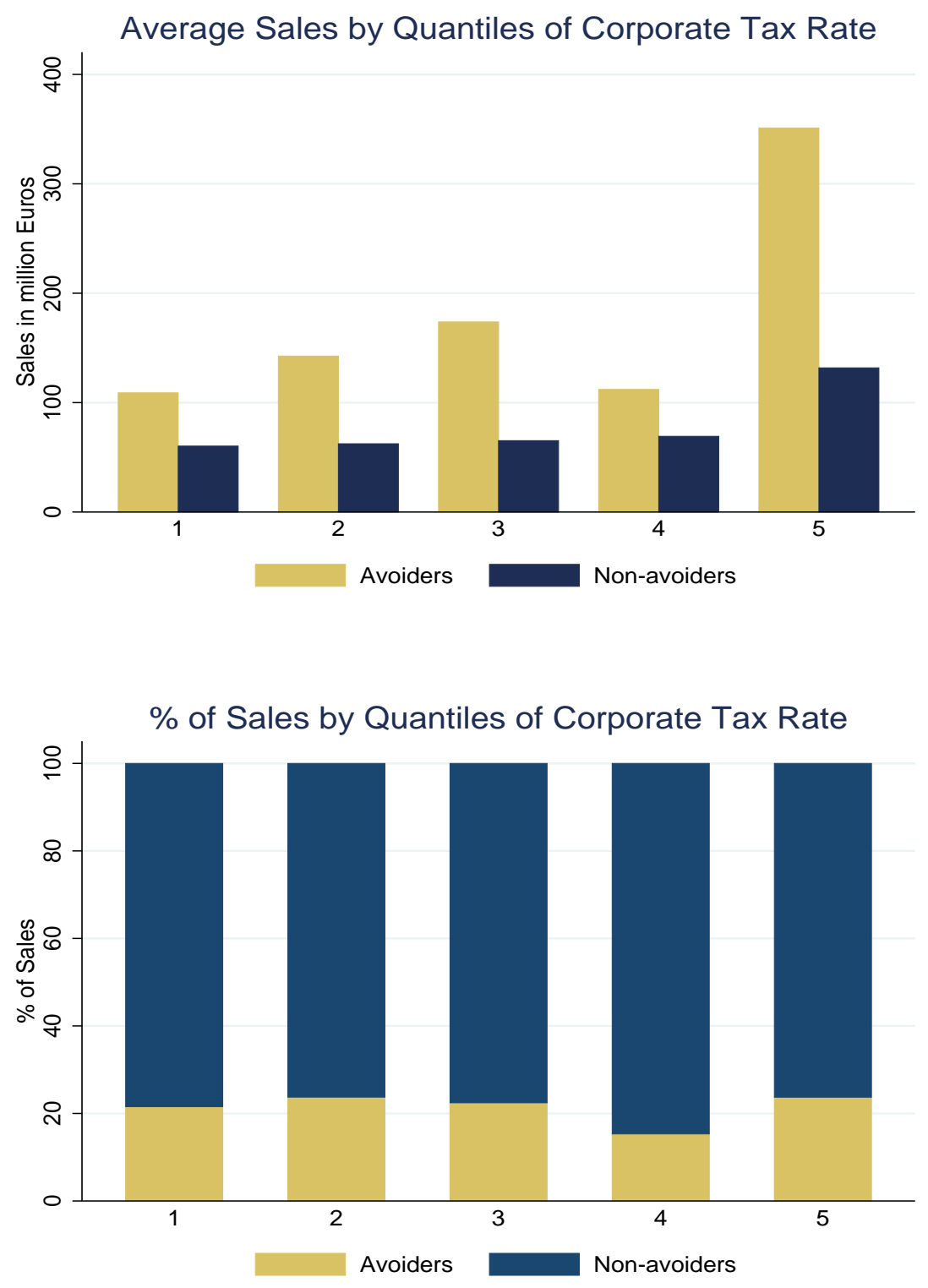

Figure 3: Sales by quintiles of corporate tax rate 

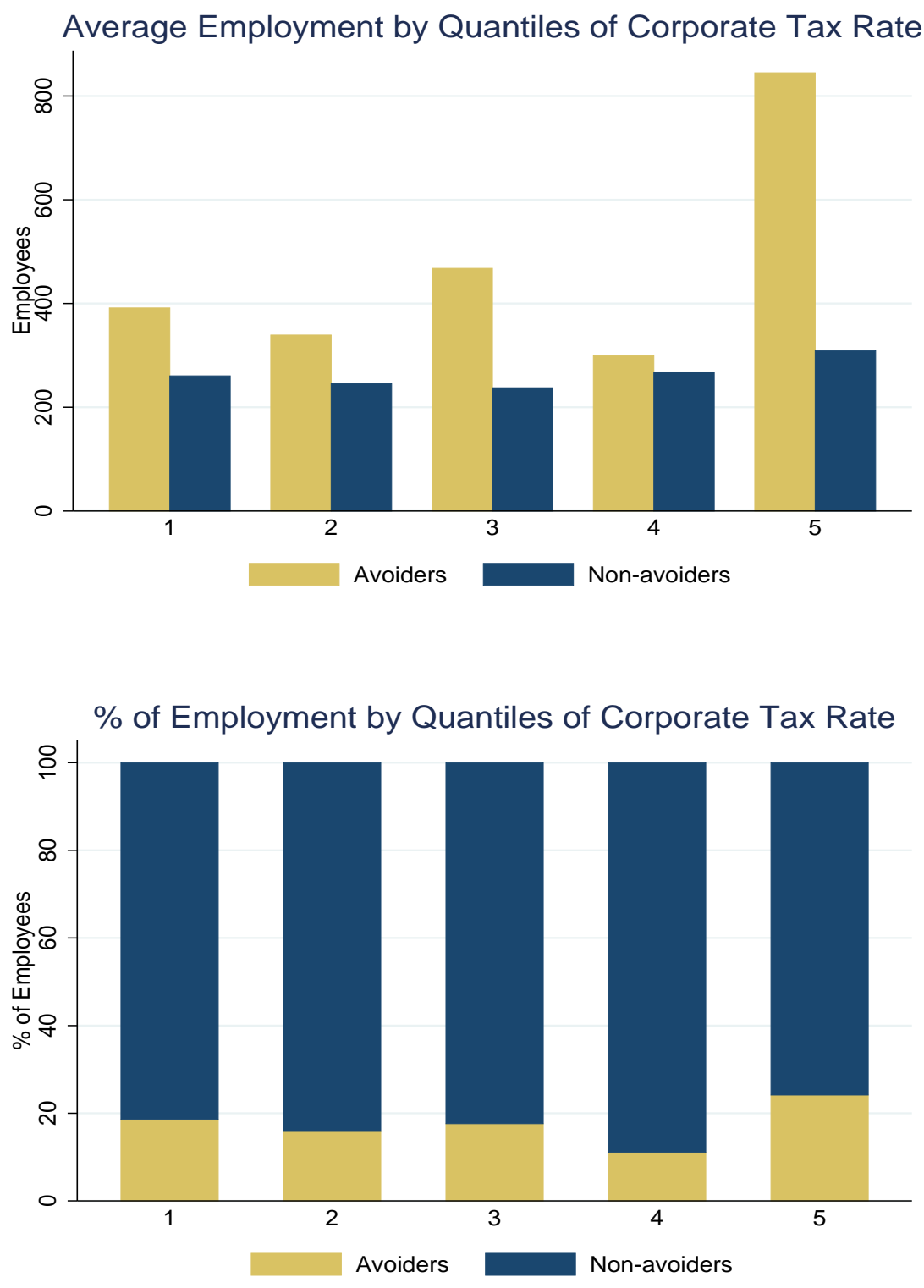

Figure 4: Employment by quintiles of corporate tax rate 